\title{
Techno-Economic Feasibility of Solar Powered Electric Vehicle Charging Stations in West Virginia
}

Houssem Eddine Younes

hy0027@mix.wvu.edu

Follow this and additional works at: https://researchrepository.wvu.edu/etd

Part of the Energy Systems Commons

\section{Recommended Citation}

Younes, Houssem Eddine, "Techno-Economic Feasibility of Solar Powered Electric Vehicle Charging Stations in West Virginia" (2020). Graduate Theses, Dissertations, and Problem Reports. 7722.

https://researchrepository.wvu.edu/etd/7722

This Problem/Project Report is protected by copyright and/or related rights. It has been brought to you by the The Research Repository @WVU with permission from the rights-holder(s). You are free to use this Problem/Project Report in any way that is permitted by the copyright and related rights legislation that applies to your use. For other uses you must obtain permission from the rights-holder(s) directly, unless additional rights are indicated by a Creative Commons license in the record and/ or on the work itself. This Problem/Project Report has been accepted for inclusion in WVU Graduate Theses, Dissertations, and Problem Reports collection by an authorized administrator of The Research Repository @ WVU. For more information, please contact researchrepository@mail.wvu.edu. 
Houssem Eddine Younes

Follow this and additional works at: https://researchrepository.wvu.edu/etd

Part of the Energy Systems Commons 


\title{
Techno-Economic Feasibility of Solar Powered Electric Vehicle Charging Stations in West Virginia
}

\author{
Houssem Eddine Younes
}

Problem Report submitted

to the Statler College of Engineering and Mineral Resources

at West Virginia University

in partial fulfillment of the requirements for the Master's degree of

Energy System Engineering

Hailin Li, Ph. D., Chair

Roger Chen, Ph. D.

Jignesh Solanki, Ph. D.

Morgantown, West Virginia

2020

Keywords: Photovoltaics, Electric Vehicles, Battery Storage, Techno-economic analysis 


\begin{abstract}
Techno-Economic Feasibility of Solar Powered Electric Vehicle Charging Stations

in West Virginia
\end{abstract}

Houssem Eddine Younes

This project explores the techno-economic feasibility of installing a photovoltaic (PV) system to power electric vehicle (EV) charging stations in West Virginia. A case study of a parking garage charging station is considered. The PV system performance and economic feasibility are assessed for two different system configurations and two financial scenarios. Two system variations one including PV only and another with on-site storage battery are modelled using the System Advisor Model (SAM) developed by the National Renewable Energy Laboratory. Initial technical specifications of the PV system, battery system and EV chargers were selected as a reference case. Through parametric simulation, the variation of PV system size with battery capacity shows trade-offs between achieving maximum self-consumption and sufficiency and profitability of the system. Furthermore, cost sensitivity and two financing scenarios including direct ownership of the system and a Power Purchase Agreements (PPA) were investigated. The impact of net-metering and trading renewable energy credits on the return of investment is also discussed. Based on the data derived in this research, the following conclusions can be derived: (1) The PV-EV charging station is economically not feasible compared to grid-EV charging system when the environmental benefit is not accounted for; (2) when electricity produced by PV is converted to gasoline on a vehicle mileage operation basis, the PV-EV scenario is feasible when the price of gasoline is $\$ 2.35 /$ gallon or higher without accounting for the environment benefit and differences in vehicle cost; (3) PV system is feasible if the green energy is sold to a high-tech company with the market price of $\$ 100 / \mathrm{MWh}$ considered; (4) PV system is feasible if the system is owned by a third-party and the PPA price is less than 7 cents $/ \mathrm{kWh}$. 


\section{ACKNOWLEDGMENTS}

I would like to thank the U.S Department of State and the Fulbright program for offering me the opportunity to pursue this master's program at West Virginia University.

I would like to thank Dr. Hailin Li for his continuous support during this program and his guidance in the elaboration of this report.

I would like to thank Dr. Roger Chen and Dr. Jignesh Solanki for their support of this project and commitment to be part of my committee.

I would like to thank my parents and my sisters for their endless care and support throughout this journey.

Finally, I would like to thank my fiancé Roua for her love, constant support and encouragements. 


\section{TABLE OF CONTENTS}

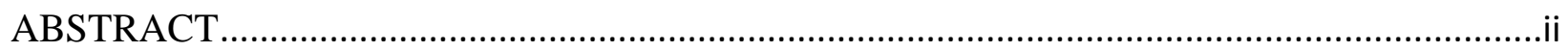

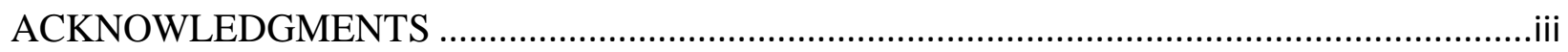

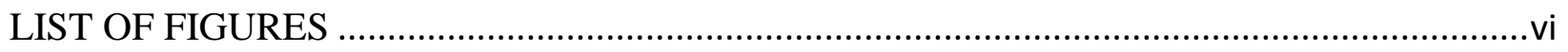

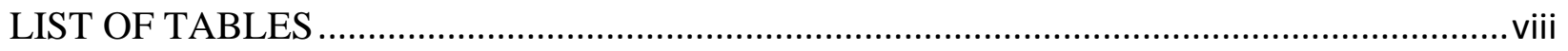

LIST OF ABBREVIATIONS AND SYMBOLS ................................................................... ix

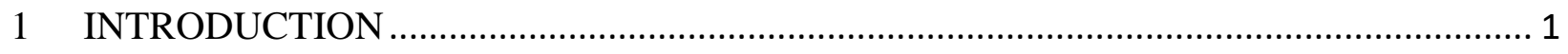

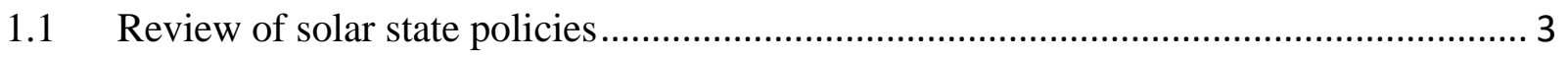

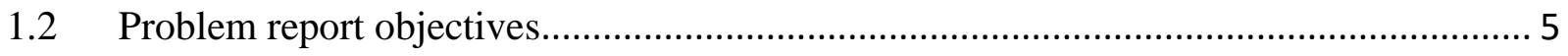

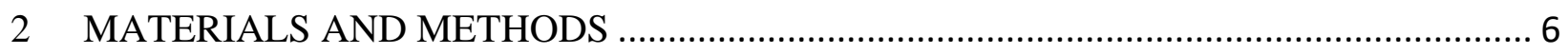

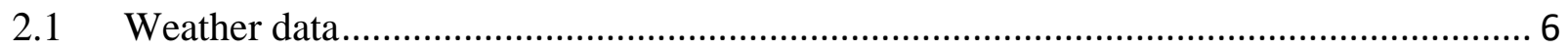

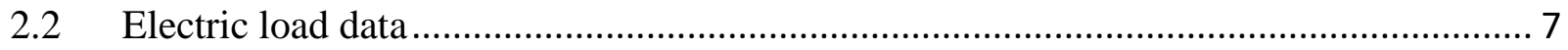

$2.3 \quad \mathrm{PV} / \mathrm{EV}$ charging station simulation...................................................................... 12

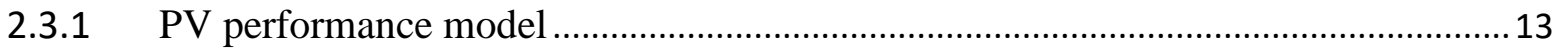

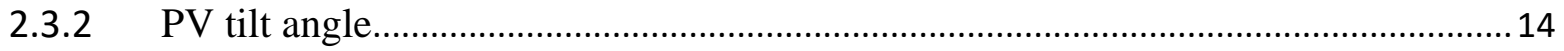

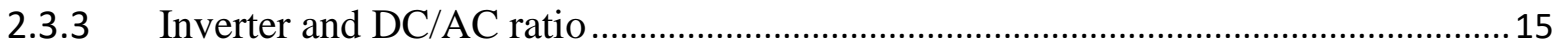

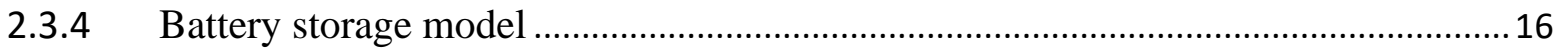

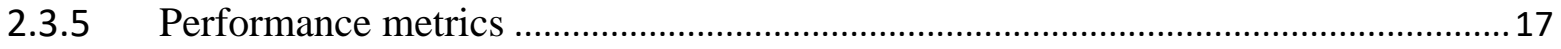

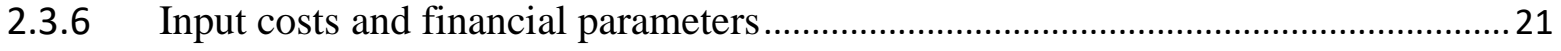

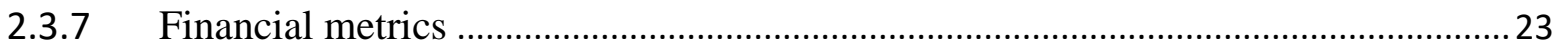

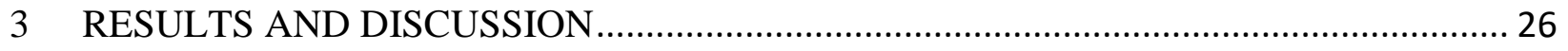


3.1 Reference case: PV system without energy storage ........................................... 26

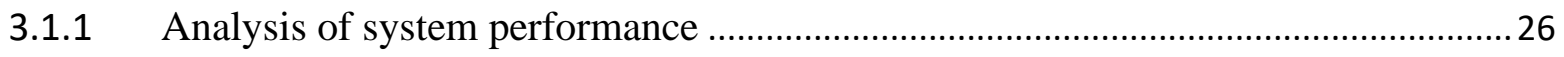

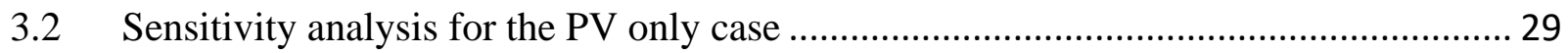

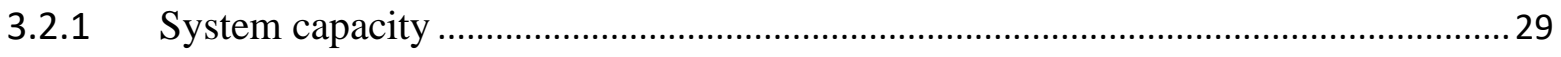

3.2.2 Cost per installed capacity .............................................................................. 31

3.2.3 Solar renewable energy credit price ................................................................... 31

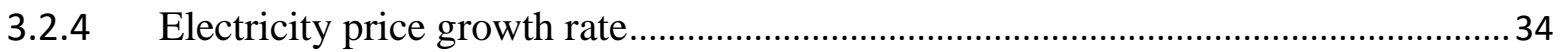

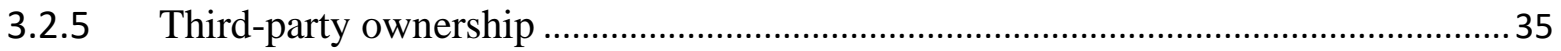

3.3 System 2: PV system with battery storage .................................................... 36

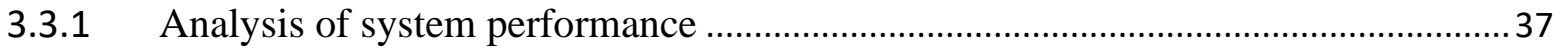

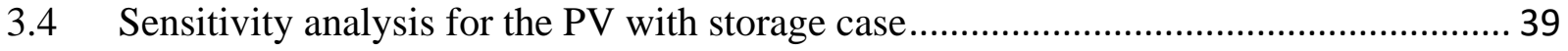

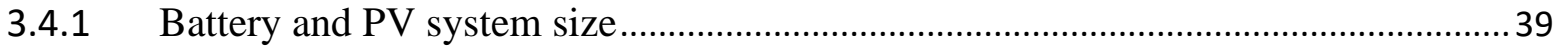

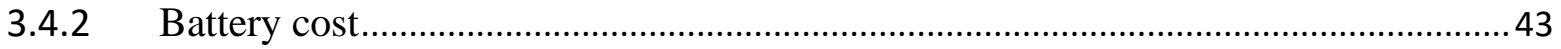

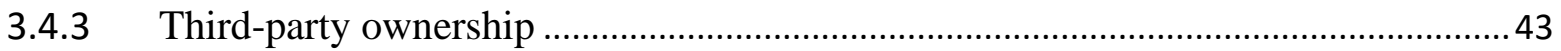

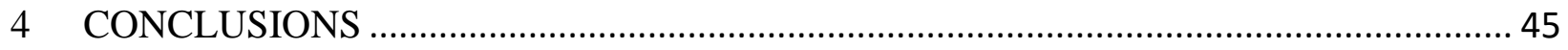

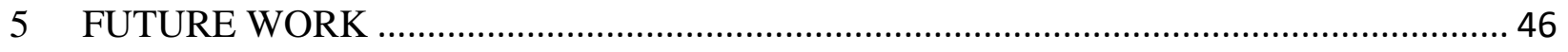

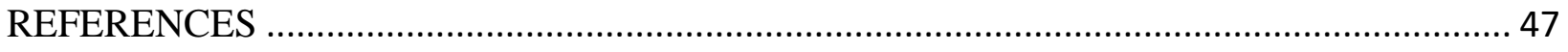

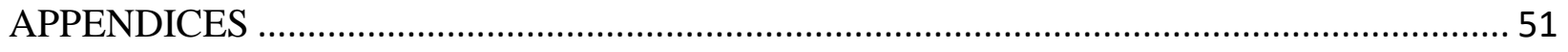

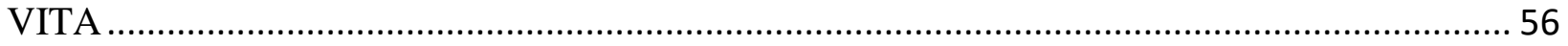




\section{LIST OF FIGURES}

Figure 1: US States with SREC markets [13] .......................................................... 4

Figure 2: Global horizontal irradiance in Morgantown, WV ................................................ 7

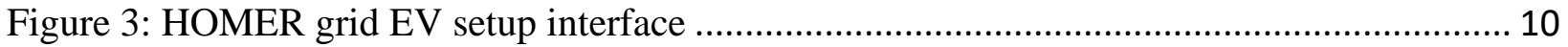

Figure 4 : Assumed EV arrival frequency for workplace charging ...................................... 11

Figure 5: Example of charging station load profile for the first week of January ..................... 11

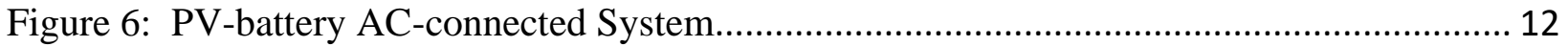

Figure 7: Single diode model equivalent circuit .......................................................... 14

Figure 8: I-V characteristics of a PV cell for given irradiance and temperature levels.............. 14

Figure 9: Determination of the optimal PV tilt angle in Morgantown, WV ............................. 15

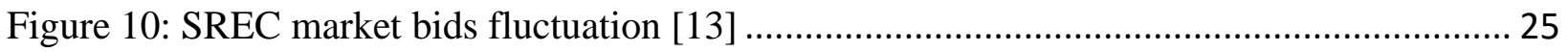

Figure 11: Hourly PV output and charging station load demand for sample weeks in January

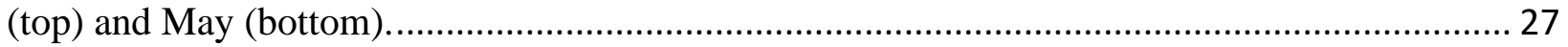

Figure 12: Monthly self-consumption and self-sufficiency rates ..................................... 27

Figure 13: Peak demand reduction with 100kW PV system ............................................ 28

Figure 14: Monthly PV production, electricity load and excess energy .................................... 29

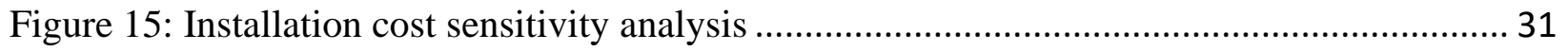

Figure 16: Variation of the net present value with SREC prices in Ohio................................ 33

Figure 17: Variation of the net present value with SREC prices .......................................... 33

Figure 18: Variation of the simple payback period with SREC prices .................................... 34

Figure 19: Variation of the net present value with electricity escalation rate .......................... 35 
Figure 20: Variation of net present value with the PPA price (cents/kWh) ........................... 36

Figure 21: Power dispatch for the PV+storage system for a sample day in May...................... 38

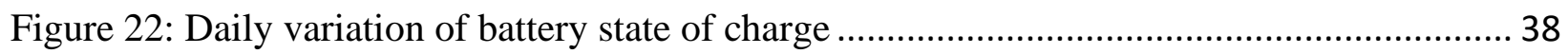

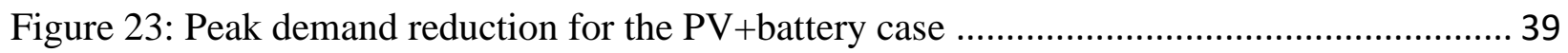

Figure 24: NPV with varying PV system and battery size ............................................ 40

Figure 25: Variation of the self-sufficiency rate with PV and battery size ............................. 40

Figure 26: Variation of the self-consumption rate with PV and battery size............................ 41

Figure 27: variation of NPV with battery cost for the optimal case ..................................... 43

Figure 28: Variation of the net present value with PV system and battery size for a PPA price of

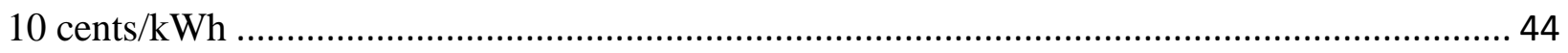

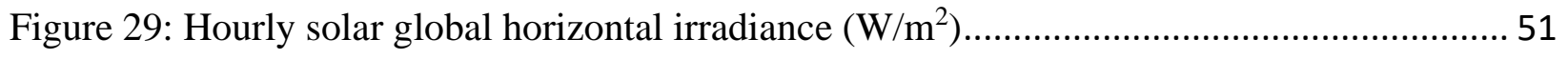

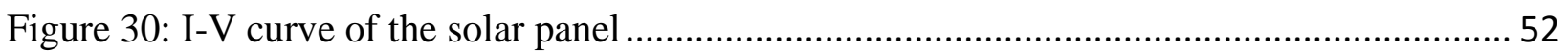

Figure 31: Inverter efficiency at different power output levels ....................................... 53

Figure 32: Average daily profile for the electric vehicle charging station .............................. 55 


\section{LIST OF TABLES}

Table 1: Summary of Solar policies in West Virginia ......................................................... 5

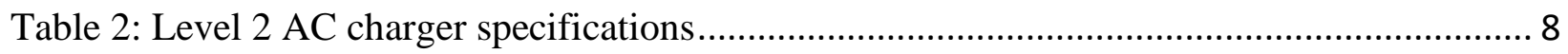

Table 3: Electric vehicle fleet input parameters ................................................................. 9

Table 4: Assumed variability factors for charging duration and arrival frequency .................... 10

Table 5: $\mathrm{CO}_{2}$ emissions using gasoline, grid charged EVs and solar charged EVs.................... 20

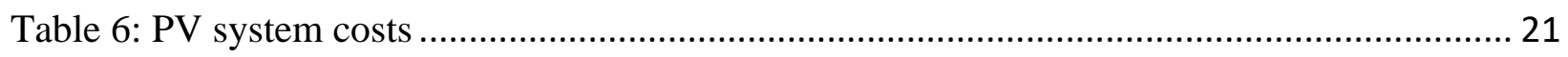

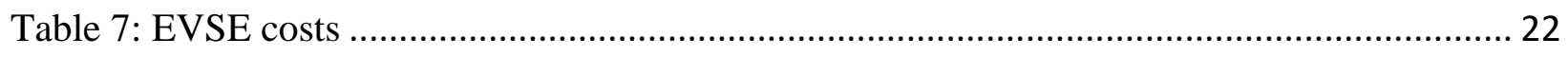

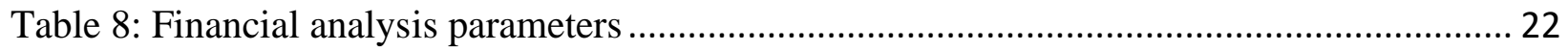

Table 9: Utility rates (based on Monpower General service ' $\mathrm{C}$ ' tariff [25]) ............................. 22

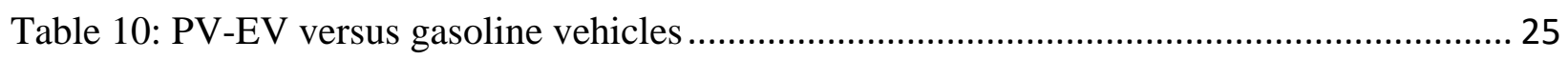

Table 11: Summary of PV system performance for different array sizes.............................. 30

Table 12: Summary of PV system performances with the battery ....................................... 42

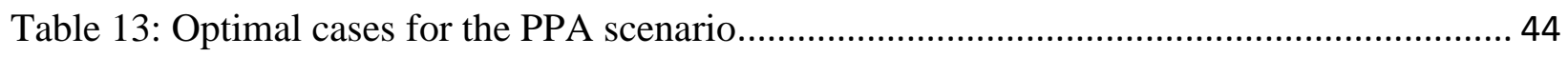

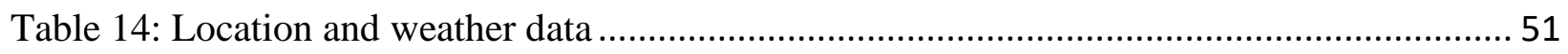

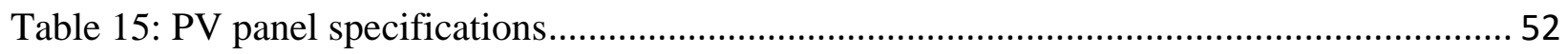

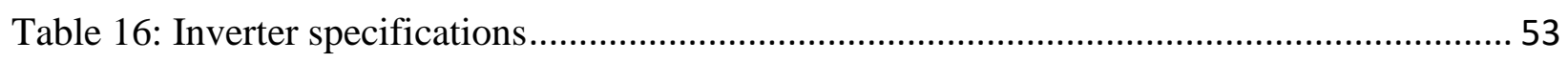

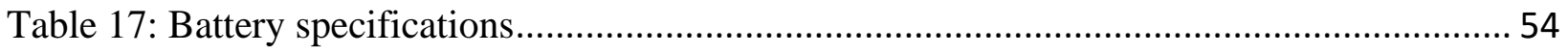




\section{LIST OF ABBREVIATIONS AND SYMBOLS}

$\begin{array}{ll}\text { Abbreviation } & \text { Definition } \\ \text { AC } & \text { Alternating Current } \\ \text { DC } & \text { Direct Current } \\ \text { EV } & \text { Electric Vehicle } \\ \text { EVCS } & \text { Electric Vehicle Charging Station } \\ \text { EVSE } & \text { Electric Vehicle Supply Equipment } \\ \text { ITC } & \text { Investment Tax Credit } \\ \text { PPA } & \text { Power Purchase Agreement } \\ \text { PV } & \text { Photovoltaic } \\ \text { RPS } & \text { Renewable Portfolio Standard } \\ \text { SAM } & \text { System Advisor Model } \\ \text { SREC } & \text { Solar Renewable Energy Credit } \\ \text { STC } & \text { Standard Test Conditions } \\ \text { TMY } & \text { Typical Meteorological Year }\end{array}$




\begin{tabular}{|c|c|c|}
\hline Variable & Unit & Definition \\
\hline $\mathrm{C}$ & $\mathrm{Ah}$ & Battery capacity \\
\hline $\mathrm{CF}_{\text {net }}$ & $\$$ & Net Cashflow \\
\hline $\mathrm{C}_{\max }$ & $\mathrm{Ah}$ & Maximum battery capacity \\
\hline $\mathrm{CO}_{2}$ (no PV) & Tons & $\mathrm{CO}_{2}$ emission without $\mathrm{PV}$ \\
\hline $\mathrm{CO}_{2}$ (with PV) & Tons & $\mathrm{CO}_{2}$ emission with $\mathrm{PV}$ \\
\hline DHI & $\mathrm{W} / \mathrm{m}^{2}$ & Direct Horizontal Irradiance \\
\hline DNI & $\mathrm{W} / \mathrm{m}^{2}$ & Direct Normal Irradiance \\
\hline Eevdemand & $\mathrm{kWh}$ & Total energy demand \\
\hline Eexported & $\mathrm{kWh}$ & Energy delivered from PV to the grid \\
\hline Eimported & $\mathrm{kWh}$ & Energy delivered from the grid \\
\hline$E_{\max , \text { charge }}$ & $\mathrm{kWh}$ & Maximum battery charging energy \\
\hline $\mathrm{E}_{\text {max,discharge }}$ & $\mathrm{kWh}$ & Maximum battery discharging energy \\
\hline $\mathrm{E}_{\mathrm{PV}}$ & $\mathrm{kWh}$ & Total photovoltaic energy production \\
\hline EPVtobattery & $\mathrm{kWh}$ & Energy delivered from PV to battery \\
\hline EPVtoPV & $\mathrm{kWh}$ & Energy delivered to EV rom PV \\
\hline EpVused & $\mathrm{kWh}$ & Energy directly used from PV \\
\hline ESC & $\mathrm{kWh}$ & Self-consumed energy \\
\hline GHI & $\mathrm{W} / \mathrm{m}^{2}$ & Global Horizontal Irradiance \\
\hline NPV & $\$$ & Net Present Value \\
\hline$P_{\text {battery }}$ & $\mathrm{kW}$ & Total power delivered by the batterie \\
\hline $\mathrm{P}_{\text {battery,max }}$ & $\mathrm{kW}$ & Maximum battery charging power \\
\hline PBP & Years & Payback period \\
\hline
\end{tabular}




$\begin{array}{lll}\mathrm{P}_{\text {charging }} & \mathrm{kW} & \text { Battery charging power } \\ \mathrm{P}_{\text {demand }} & \mathrm{kW} & \text { Load power demand } \\ \mathrm{P}_{\text {discharging }} & \mathrm{kW} & \text { Battery discharging power } \\ \mathrm{P}_{\text {grid }} & \mathrm{kW} & \text { Total power delivered by the grid } \\ \mathrm{P}_{\mathrm{pv}} & \mathrm{kW} & \text { Total power delivered by PV } \\ \mathrm{SCR} & \% & \text { Self-Consumption Rate } \\ \mathrm{SOC} & \% & \text { State of Charge } \\ \mathrm{SSR} & \% & \text { Self-Sufficiency Rate } \\ \mathrm{V} & \mathrm{V} & \mathrm{Battery} \mathrm{voltage} \\ \Delta \mathrm{CO}_{2} \text { (on-site) } & \% & \mathrm{CO}_{2} \text { reduction on-site } \\ \Delta \mathrm{CO}_{2} \text { (total) } & \mathrm{CO}_{2} \text { reduction in total }\end{array}$




\section{INTRODUCTION}

The United States (US) filed a complaint against Volkswagen (VW) on behalf of the United Sates Environmental Protection Agency (EPA) in 2016, following VW's violations of the Clean Air Act regarding 590,000 diesel vehicles sold in the U.S. The violation which has been discovered by researchers at West Virginia University, consisted in Volkswagen's altering of algorithms and calibrations that caused emissions from the vehicles to perform differently under normal operation than during emission testing. On-road emissions were revealed to be 9 to 38 times higher than the limit [1] . The discovery led to a settlement in which VW agreed to spend $\$ 14.7$ billion to fund projects intended to make up for the additional pollution that the diesel engines produced. $\$ 2.7$ billion were allocated to an Environmental Mitigation Trust that would allow states to mitigate some of the damage done by VW to the environment. As required by the Trust Agreement, West Virginia has been named a "beneficiary" of the Environmental Mitigation Trust. Therefore, West Virginia is eligible to claim its trust allocation of $\$ 12.1$ million. According to the West Virginia beneficiary mitigation plan submitted in 2019 [2], West Virginia intends to allocate 5\% of these funds to projects related to the installation of electric vehicle charging equipment, with an emphasis on locations within, or near, the campuses of West Virginia University.

Currently, all the EV charging stations in West Virginia use the utility grid to supply the energy demand. However, relying on the grid to power EV charging stations may not really have a significant benefit on the environment. In fact, the claim about EVs having zero emissions is a common misconception, unless the energy used to power the EV is produced using a carbon-free and clean source. According to the research conducted by the National Renewable Energy Laboratory (NREL) [3], in regions where the grid has a high carbon intensity, the carbon dioxide $\left(\mathrm{CO}_{2}\right)$ emissions reduction is not significant. This is especially true in West Virginia where $92 \%$ 
of the electricity is produced by burning Coal and around $5 \%$ is produced by renewable energy sources [4]. The combination of solar photovoltaics (PV) with electric vehicle supply equipment (EVSE) can help address these issues. In recent years, the PV-EV charging stations (PV-EVCS) gained more attention due to the continuous decline in PV system costs, the increasing the number of EVs and the concerns about the harmful effects of greenhouse gases [5].

Other than the environmental benefits, integrating PV in charging stations has the potential to produce significant cost savings for the system owner. Connecting multiple EVSE to the grid, for example in the case of workplace charging, can result in high demand charges caused by spikes in power usage. These demand charges are a significant portion of the electricity bill for commercial customers. They are determined by the highest 15-minute peak occurring for each billing cycle. By adding PV, the peak demand can be lowered leading to significant savings on the electricity bill. However, careful design of the system is necessary for the project to be technically and economically viable.

One of the major disadvantages of PV is the variability of energy production [6]. The research done by Mesentean et al. [7] discusses how this can be mitigated by adding local storage battery along with the PV array and EVSE. The battery is charged by the excess solar energy and then discharged when the PV generation is not enough to meet the load. The battery can also contribute to reducing peak demand and minimize its effect on the grid [8]. However, a battery is an expensive component which increases the capital cost of the system and may make the system economically infeasible. Several works on the optimization of the system design to increase its profitability have been reported. Multivariable optimization of the PV system and battery size was addressed by Dai et al. [9] using a modelling approach with the target of minimizing the overall cost of energy consumed. The amount of avoided emissions was however not considered in 
choosing the optimal design. Research conducted by Gudmunds et al. [10] investigated the effect of battery size on the self-sufficiency rate, however the analysis was limited to a residential application.

\subsection{Review of solar state policies}

When designing a PV system, it is important to consider economics and regulations. Currently, the major barrier for large-scale deployment of PV systems in West Virginia is the high upfront costs, poor return on investment and lack of supporting policies [11].

The economics of solar systems are largely dependent on Federal and State policies. Currently, tax-paying system owners can decrease their costs through an investment tax credit (ITC) offered as an incentive by the Federal Government. ITC is an incentive given to the system owner as a percentage of the total investment. The ITC is currently at $26 \%$ and is set to decrease to $22 \%$ in 2021 and a permanent $10 \%$ after 2022 . ITCs are a very important incentive for solar systems since they reduce investment costs and allow faster payback periods. However, they are offered only to tax paying owners. University campuses, schools, churches or government entities who don't pay taxes are not eligible for this incentive. Such entities may be able to profit from installing PV systems by entering into Power Purchase Agreements (PPA) [12]. A PPA is an agreement with a third-party to install and operate a PV system while paying them a fixed price for the energy produced, usually below the utility rate. These contracts are typically set for a specified period usually between 15 and 25 years. PPAs are legal in 28 states including Virginia, Ohio, Pennsylvania, Maryland, and Georgia, but not in West Virginia yet.

Additionally, in many states, solar system owners can increase savings through a netmetering program. Net-metering is a program offered by utilities that credits solar system owners 
for the excess amount of energy they export to the grid. Any excess energy produced by the solar system is injected in the grid and adds a monthly $\mathrm{kWh}$ credit that gets subtracted from the monthly bill. Any remaining credits are rolled over to subsequent months and any credits left at the end of the year are sold at a rate equal to the utility energy rate. Net-metering is offered in West Virginia for all utilities.

PV system owners can also increase their return on investment by trading solar renewable energy credits (SRECs) in specific markets. SRECs are environmental certificates generated for each MWh produced by the PV system. Currently there is no market for trading SRECs in West Virginia as there is no Renewable portfolio standard (RPS) in the state. System owners can still trade SRECs in the Ohio market. In addition, many corporations like Google, Amazon and Facebook buy SRECs to offset their greenhouse gas emissions and meet their corporate sustainability goals.

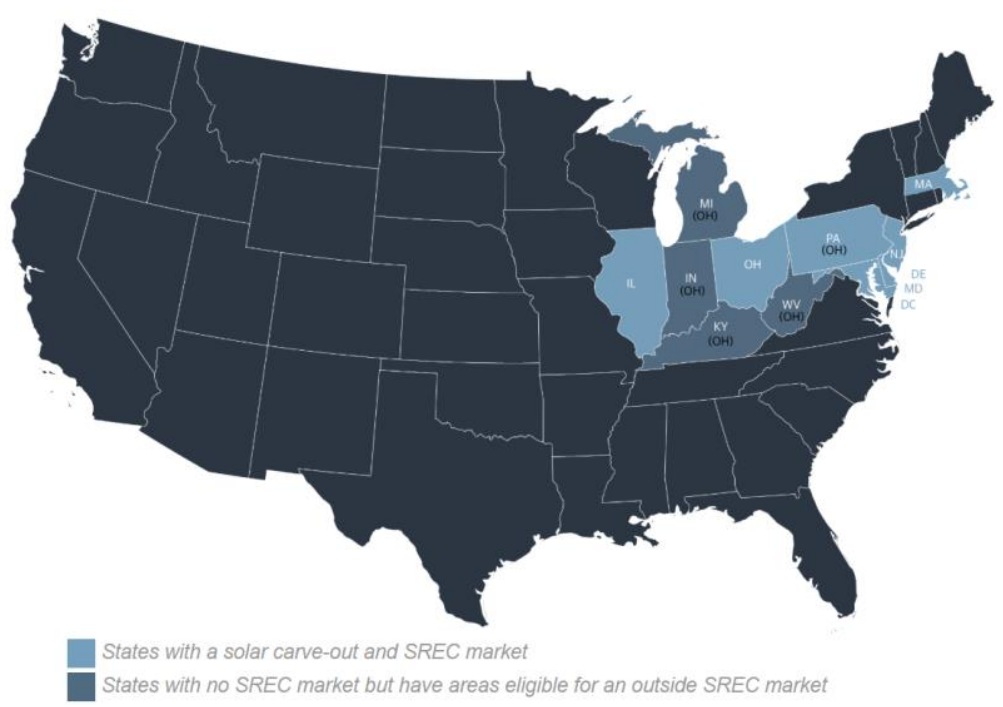

Figure 1: US States with SREC markets [13] 
Table 1 illustrates the regulatory and financial programs available in West Virginia:

Table 1: Summary of Solar policies in West Virginia

\begin{tabular}{|l|l|}
\hline Structure & Is it available in WV? \\
\hline Net metering & Yes \\
\hline Tradeable SRECs & Yes (out of state) \\
\hline Power Purchase Agreements & No \\
\hline Investment tax credits & Yes \\
\hline
\end{tabular}

\subsection{Problem report objectives}

In this report a commercial PV system for an EVCS was modeled in the System Advisor Model (SAM) software in order to determine its feasibility in West Virginia. Two system variants were considered: PV only and PV with battery storage. The EV charging load was estimated and the energy production was calculated based on weather data from WV. The PV array and system sizes were varied to determine the optimal design under different cost scenarios and financing options. The contributions of this research consist in:

- Demonstrating the environmental and economic benefits of PV-EV systems compared to grid-charged EVs and gasoline vehicles.

- Investigating the economic feasibility of the PV system under different policies, costs and financing options.

- Determining the effect of different PV system and battery sizes on the energy performance and the economic feasibility of the system. 


\section{MATERIALS AND METHODS}

This chapter details the data sources and simulation tools used to model the PV-EV charging station and perform the financial analysis.

\subsection{Weather data}

The PV system performance and financial analysis are calculated using SAM [14]. SAM is a free software developed by the National Renewable Energy Laboratory (NREL) in collaboration with Sandia National Laboratories with funding from the Department of Energy (DOE). It is used for predicting the performance of renewable energy systems and analyzing the financial feasibility of residential, commercial, and utility-scale grid-connected projects. SAM performs detailed performance and financial analysis for a variety of photovoltaic system configurations, including PV only and PV with Storage for peak shaving analysis. Tools for optimization, parametric, statistical analysis and user-defined scripts are also available. Typical Meteorological Year (TMY) weather datasets are used as input to calculate the hourly production of the PV system. TMY files are available for many locations in the United States. Each file consists of an hourly weather dataset derived from long term measurements. The data are processed by selecting" typical" months to represent the long-term properties of the data. The input files include the following datasets:

- $\quad$ Direct normal (beam) irradiance, DNI $\left(\mathrm{W} / \mathrm{m}^{2}\right)$

- Diffuse horizontal irradiance, DHI $\left(\mathrm{W} / \mathrm{m}^{2}\right)$

- $\quad$ Dry-bulb temperature $\left({ }^{\circ} \mathrm{C}\right)$

- Dew-point temperature $\left({ }^{\circ} \mathrm{C}\right)$

- $\quad$ Relative humidity (\%), for single-year files only 
- Atmospheric pressure (mbar)

- Wind speed at 2 meters above the ground $(\mathrm{m} / \mathrm{s})$

- Wind direction $\left({ }^{\circ} \mathrm{E}\right.$ of $\left.\mathrm{N}\right)$

- Albedo: Ratio of diffuse radiation reflected by the ground surface

By summing the beam, diffuse and reflected components of the solar irradiance the global horizontal irradiance (GHI) is calculated. Figure 2 shows the monthly average GHI in W/m $\mathrm{m}^{2}$ in Morgantown WV.
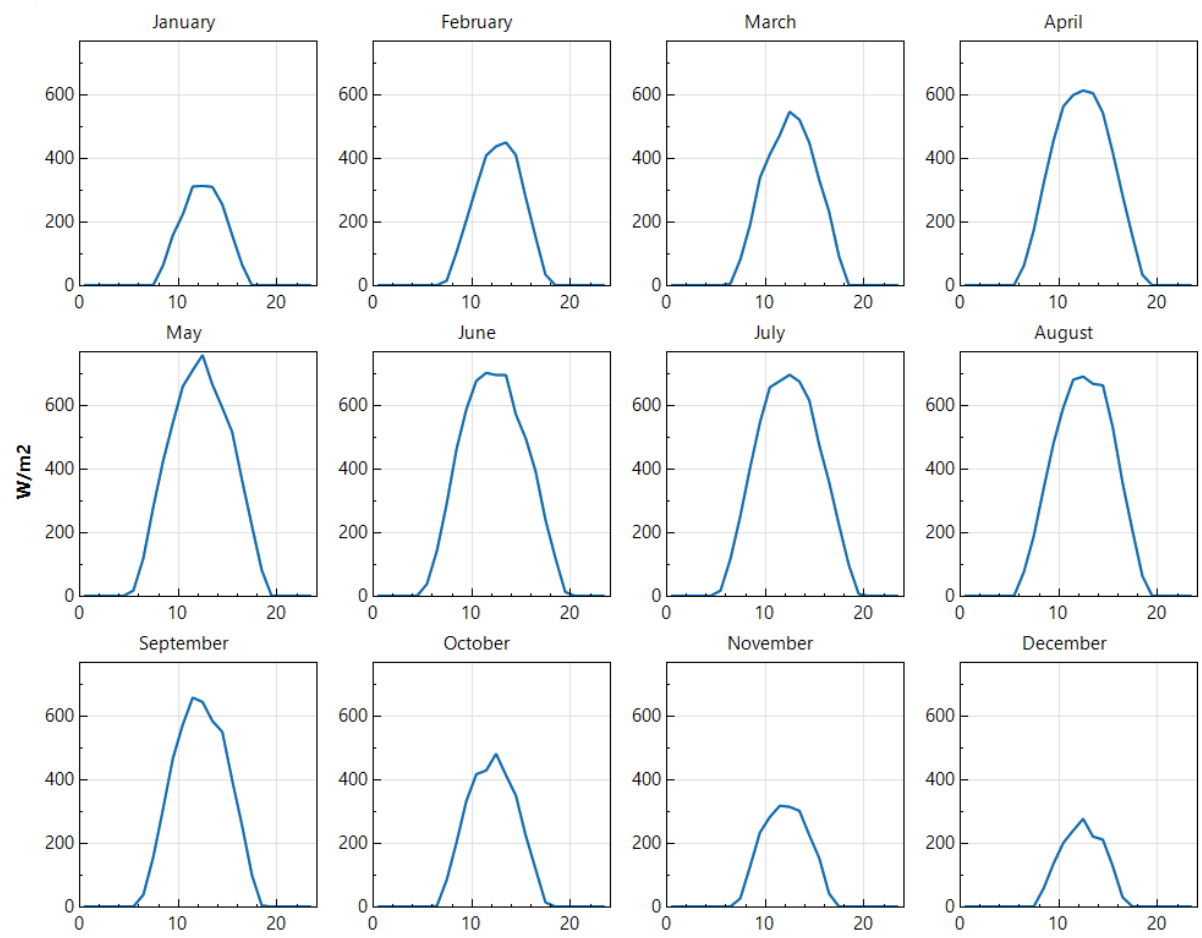

Figure 2: Global horizontal irradiance in Morgantown, WV

\subsection{Electric load data}

EVSE power ratings differ depending on the type of charger. There are two types of charging: alternating current (AC) and direct current (DC). AC chargers supply power from the grid directly to the vehicle where a conversion from AC to DC happens inside the vehicle's on- 
board chargers. In the DC charger the conversion happens outside of the vehicle and inside the charger itself. Level 1 is the slowest of the chargers, typically used for residential applications, it uses a 120V AC connection and supplies a power of about 1.4kW. Level 2 requires a 208/240V $\mathrm{AC}$ connection and has a power range of $6.6 \mathrm{~kW}$ to $19.2 \mathrm{~kW}$. Charging times with level 2 charging are in the order of 4 to 8 hours and it is mostly used in commercial and public charging. Level 3 is the DC fast charger which can deliver between $50 \mathrm{~kW}$ and $150 \mathrm{~kW}$ in charging power. It is used in commercial and public charging and it can charge an EV in less than an hour. For this project, a 7.2kW AC level 2 from the manufacturer Leviton was used for calculations. Specifications are summarized in Table 2:

Table 2: Level 2 AC charger specifications

\begin{tabular}{|c|c|}
\hline Charger designation & LEV-EVR30-B1C \\
\hline Charger type & AC level II \\
\hline Maximum charging current & $30 \mathrm{~A}$ \\
\hline Operating voltage & $240 \mathrm{~V}$ \\
\hline Maximum charging power & $7.2 \mathrm{~kW}$ \\
\hline Vehicle Connector type & $\mathrm{SAE} \mathrm{J1772}$ \\
\hline Operating temperature & $-30^{\circ} \mathrm{C}$ to $50^{\circ} \mathrm{C}$ \\
\hline Cable length & $18 \mathrm{ft}$ \\
\hline
\end{tabular}

Without real-world EV operation data, the prediction of the load for electric charging stations can be a very complex modeling task since it involves many uncertainties. To generate a load profile for the charging station, the number and type of vehicles, arrival schedule, travelled distance and average charging times must be assumed. In addition, the state of charge of each vehicle at the arrival and departure from the charging station must be known for each vehicle. A few methods can be found in the literature which are either data-driven or analytical. For example, 
in the research conducted by Zhang et al. [15], the charging behaviors and charging time of different groups are analyzed, and a charging load model is developed using Monte Carlo simulation. In the research done by Islam et al. [16], the daily load profile for EVs was modelled for a workplace environment using a stochastic approach. These methods are beyond the scope of work of this project report. To avoid the use of unavailable data, a software package called HOMER grid was used to generate the aggregate load profile of a predetermined fleet of electric vehicles with an assumed number of variables.

The profile was constructed in HOMER grid based on a population of a $100 \mathrm{EV}$ s including 4 of the most common models (Nissan Leaf, Tesla Model S, Chevrolet Bolt and BMWi3) (Figure 3). The proposed charging station will have 10 level $2(7.2 \mathrm{~kW})$ charging ports. An average of 15 charging sessions per day is assumed and the daily arrival frequency (visits/hour) is set to a default workplace charging pattern in HOMER (Figure 4). The average charging time per session is set to 4 hours. The initial states of charges for vehicles at the beginning of each charging session are randomized within the software. To get a more realistic representation of the charging patterns during the year, HOMER allows the input of hourly and daily variability factors of the charging frequency and duration. The input parameters used are summarized in Tables 3 and 4 :

Table 3: Electric vehicle fleet input parameters

\begin{tabular}{|c|c|c|c|c|}
\hline Vehicle Model & $\begin{array}{c}\text { Proportion of } \\
\text { EV population }\end{array}$ & $\begin{array}{c}\text { Maximum } \\
\text { charging power } \\
(\mathrm{kW})\end{array}$ & $\begin{array}{c}\text { Average charging } \\
\text { time (minutes })\end{array}$ & $\begin{array}{c}\text { Fuel economy } \\
(\mathrm{kWh} / \mathrm{mile})\end{array}$ \\
\hline Nissan Leaf & 25 & 6.6 & 240 & 0.3 \\
\hline Tesla Model S & 25 & 16.5 & 240 & 0.29 \\
\hline Chevy Bolt & 25 & 7.4 & 240 & 0.29 \\
\hline BMW i3 & 25 & 7.7 & 240 & 0.3 \\
\hline
\end{tabular}


Table 4: Assumed variability factors for charging duration and arrival frequency

\begin{tabular}{|c|c|}
\hline Property & Value \\
\hline Charge duration Variability (\%) & 30 \\
\hline Day-to-day frequency Variability (\%) & 20 \\
\hline Timestep Variability (\%) & 10 \\
\hline
\end{tabular}

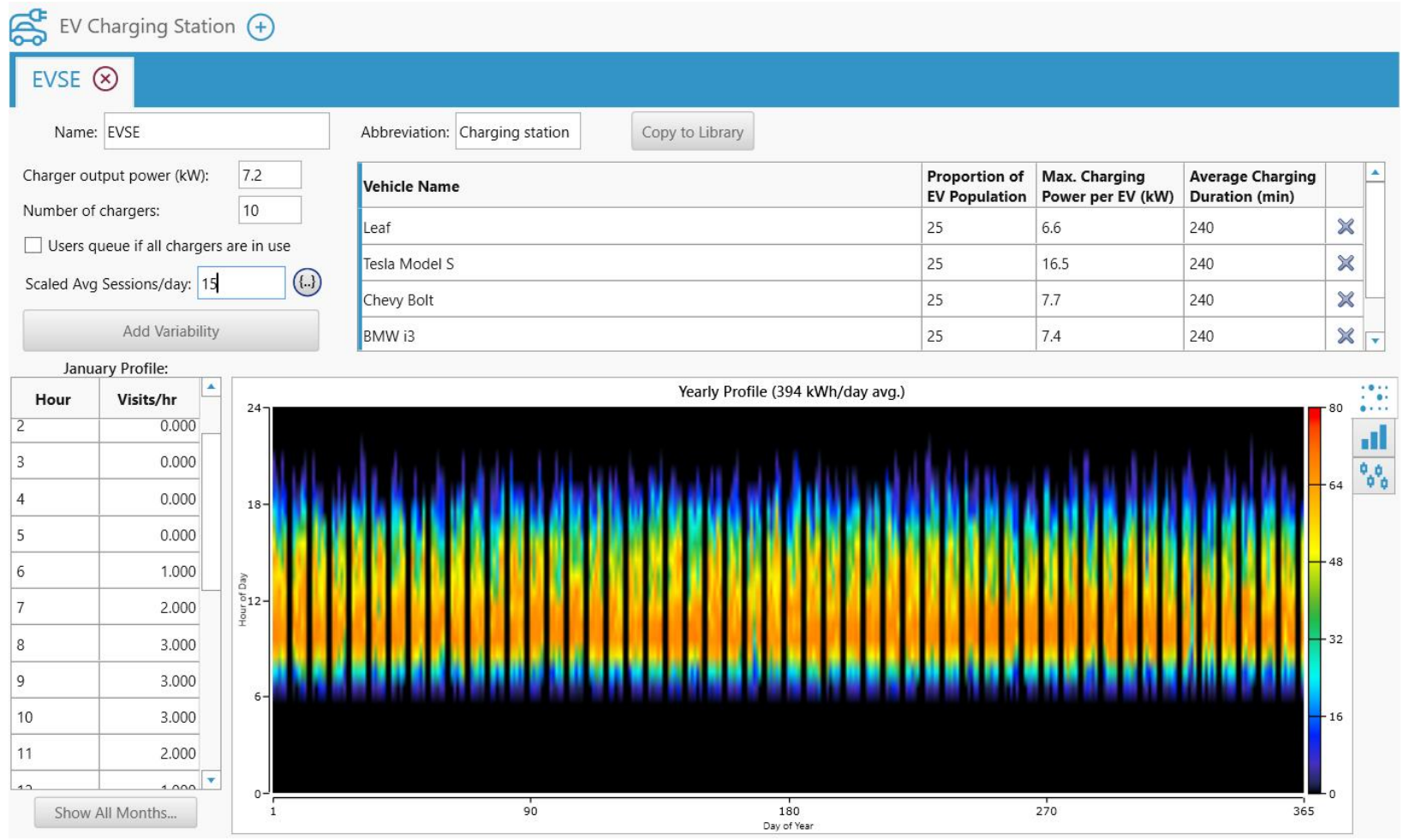

Figure 3: HOMER grid EV setup interface 


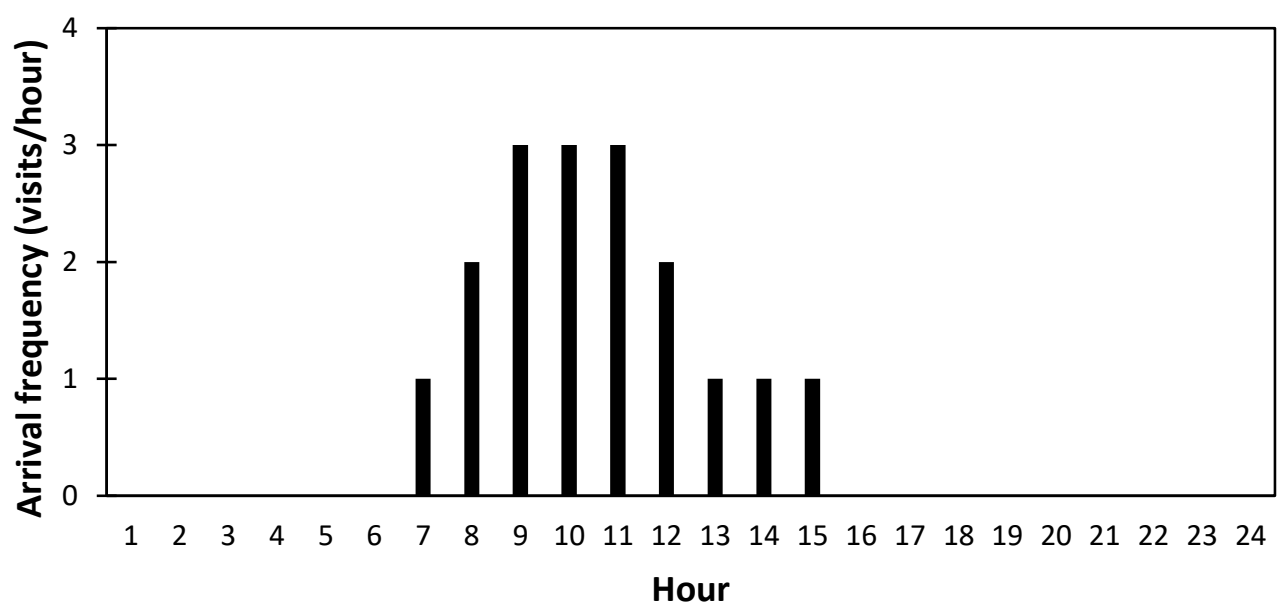

Figure 4 : Assumed EV arrival frequency for workplace charging

Based on the assumed input parameters, the hourly load profile is generated. Figure 5 shows how the load profile can vary for the first week of January. Over the year, the peak demand from the station is $72 \mathrm{~kW}$ which corresponds to all charging plugs being used simultaneously at full power. The charging station will have a total of 4672 charging sessions per year.

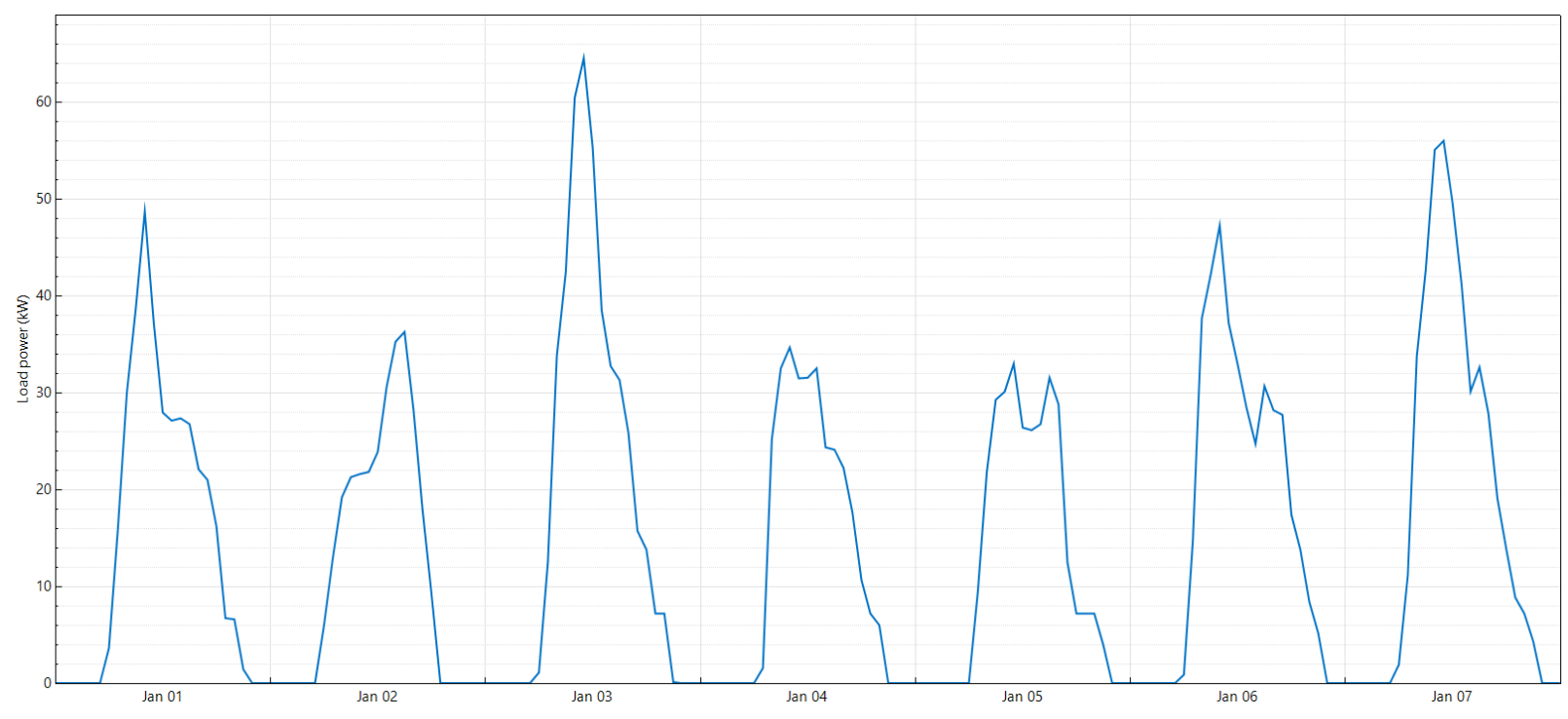

Figure 5: Example of charging station load profile for the first week of January 


\subsection{PV/EV charging station simulation}

In this report, two configurations of the PV-EV charging station are proposed: PV only and PV with a storage battery. In the first configuration the PV array and the EVSE are both connected to the grid. Since the EVSE used are AC level 2 type chargers, the PV array DC output is first converted to AC by an inverter and then supplied to the chargers. Any surplus electricity is exported to the grid. When the PV output is not enough due to low irradiance, the deficit is served from the utility grid. In the second configuration, a battery is added to the system. The battery is connected to the AC bus through a bidirectional converter. This converter has the role of converting the inverter's AC output power into DC in order to charge the batteries and converting the DC power discharged from the battery to AC in order to charge the EV (Figure 6).

The battery serves two purposes: storing the excess electricity and discharging when the PV output is not sufficient to meet the demand. The PV system first serves the EV load and any surplus is used to charge the battery first, when charging is allowed. Any surplus above what the battery can store is exported to the grid. If both the PV and the battery cannot satisfy the load, the deficit is covered by the grid. To maximize the self-sufficiency of the system, the battery is set to recharge only from the PV system.

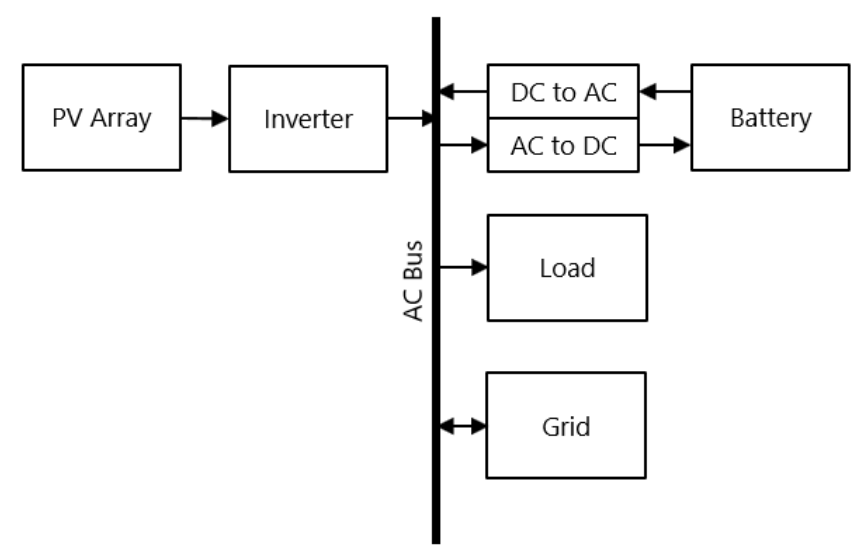

Figure 6: PV-battery AC-connected System 


\subsubsection{PV performance model}

SunPower SPR-X21-335-BLK was used as the PV module coupled with Fronius USA Symo 20.0 480V inverters. A 100kW DC PV system with 297 modules was selected for the baseline case. The system size was selected to provide $100 \%$ of the peak load demand of the charging station. SAM models the electrical characteristics of the PV module using the single diode model. It consists of an equivalent circuit comprising of a current source, a diode, a parallel resistor and a series resistor (Figure 7). For a PV module with Ns cells in series, and for a given irradiance and temperature levels, the I-V curve (Figure 8) of the PV cell is calculated by the following equation:

$$
I=I_{L}-I_{0} \exp \left(\frac{V+I R s}{n V_{t h}}\right)-1-\frac{V+I R s}{R_{s h}}
$$

$\mathrm{I}_{\mathrm{L}}$ is the photo-generated current $(\mathrm{A})$,

$\mathrm{I}_{0}$ is the dark saturation current $(\mathrm{A})$,

$\mathrm{n}$ is the diode ideality factor (unitless),

$\mathrm{V}_{\text {th }}=\mathrm{N}_{\mathrm{s}} \mathrm{kT}_{\mathrm{c}} / \mathrm{q}$ is termed the thermal voltage $(\mathrm{V})$ for the module, which is determined from cell temperature $\mathrm{T}_{\mathrm{C}}(\mathrm{K})$, Boltzmann's constant $\mathrm{k}(\mathrm{J} / \mathrm{K})$ and the elementary charge $\mathrm{q}$ (coulomb),

$\mathrm{k}$ is Boltzmann's constant $\left(1.3806610^{-23} \mathrm{~J} / \mathrm{K}\right)$,

$\mathrm{q}$ is the elementary charge (1.60218 $10^{-19}$ coulomb),

$\mathrm{R}_{\mathrm{S}}$ is the series resistance $(\Omega)$,

$\mathrm{R}_{\mathrm{sh}}$ is the shunt resistance $(\Omega)$. 
Values for Rs and Rsh are found in the selected PV module's datasheet.

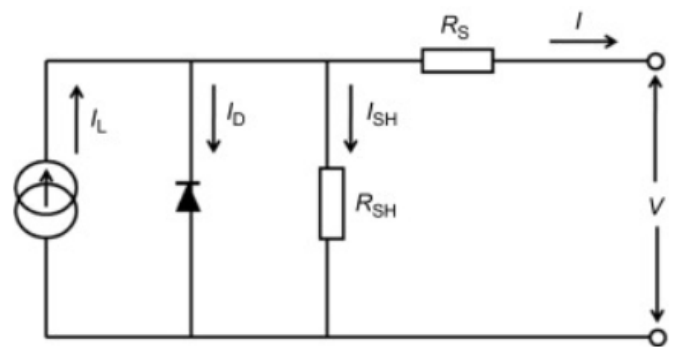

Figure 7: Single diode model equivalent circuit

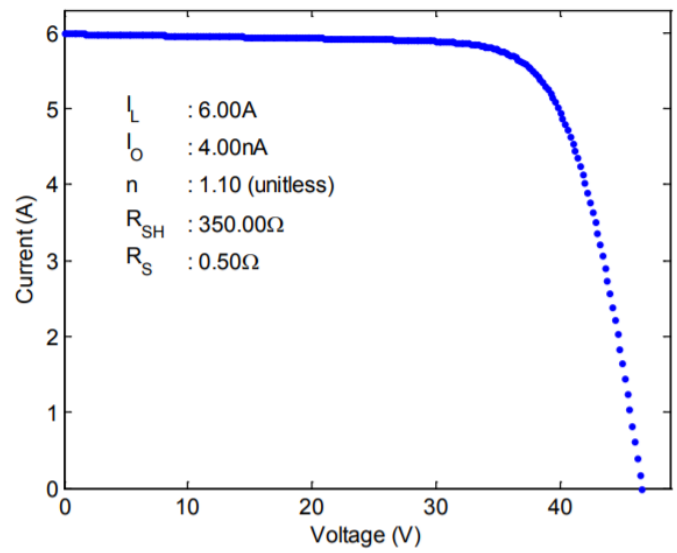

Figure 8: I-V characteristics of a PV cell for given irradiance and temperature levels

\subsubsection{PV tilt angle}

Module tilt and azimuth (orientation) angles are important parameters when designing PV systems. Studies have shown that in the northern hemisphere with panels facing south, the optimum tilt angle depends only on the latitude angle [17]. Duffie and Beckman [18] suggested an optimal tilt angle equal to the latitude $+15^{\circ}$, while Lunde and Gard [19] proposed an angle equal to the latitude $+-15^{\circ}$ for the winter and summer respectively. A common practice for fixed angle PV systems is to tilt the panels at the latitude of the location as this will yield optimal energy conversion over the entire year. To verify this assumption a parametric simulation for tilt angles 
ranging from 0 to $90^{\circ}$ was calculated in SAM to determine the maximum annual energy yield in $\mathrm{kWh} / \mathrm{kW}$ (Figure 9). The optimal tilt angle was found to be $35^{\circ}$ which is close to Morgantown's latitude of 39.61.

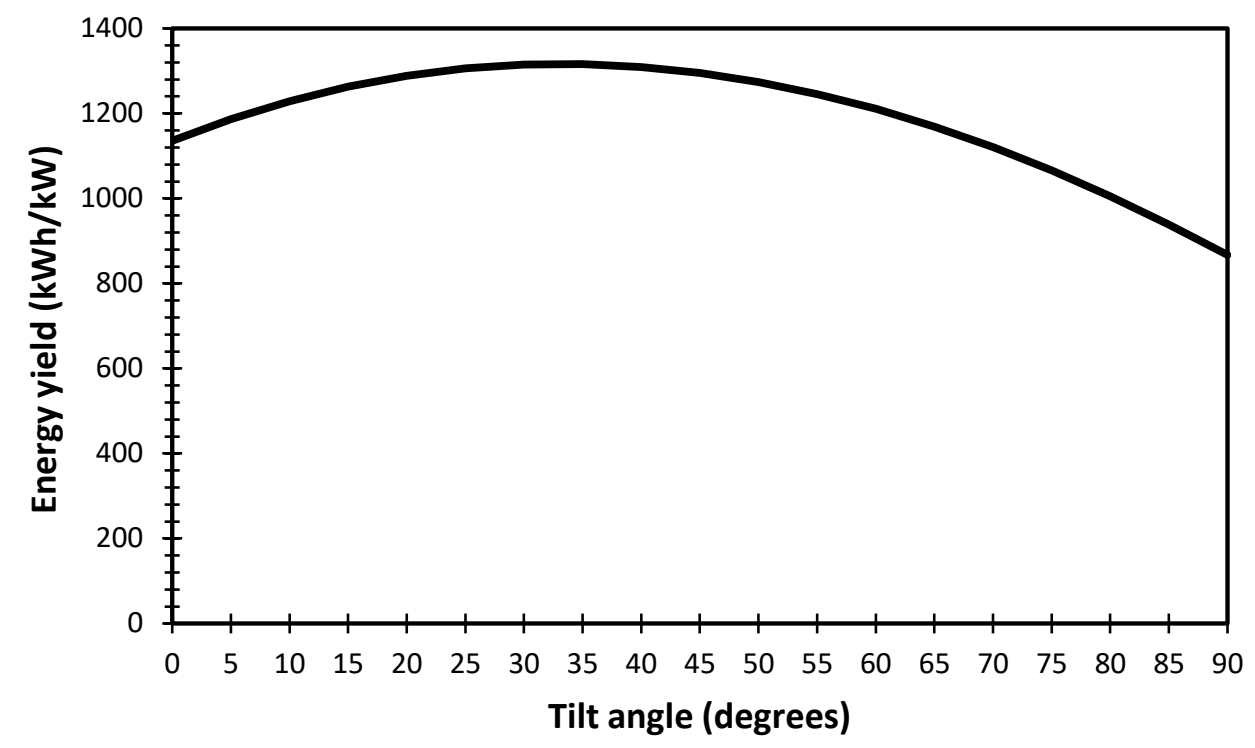

Figure 9: Determination of the optimal PV tilt angle in Morgantown, WV

\subsubsection{Inverter and $\mathrm{DC} / \mathrm{AC}$ ratio}

The PV array produces DC electricity and the role of the inverter is to convert the DC power to AC to be used by the AC load. The inverter power is often sized to be less than the PV array because the latter rarely produces power to its full nameplate power also called the standard test condition (STC) capacity. The DC/AC ratio also defined as the inverter's load ratio is the ratio of array DC power to the $\mathrm{AC}$ power of the inverter. When the DC/AC ratio is high, the $\mathrm{PV}$ array produces more power than what the inverter can handle. The inverter will then drop the voltage level to reduce the power and the lost power is known as the clipping loss of the inverter. A healthy design will minimize clipping losses and a typical value for DC/AC ratio is 1.2 . With a $100 \mathrm{~kW}$ 
DC PV array, the inverter total AC power is $80 \mathrm{~kW}$ AC. For this project four of the Fronius USA symo $20.0 \mathrm{~kW}$ AC inverters were considered.

\subsubsection{Battery storage model}

A $100 \mathrm{kWh} / 25 \mathrm{~kW}$ lithium-ion battery is chosen for the baseline case. The maximum and minimum states of charge (SOC) are set to $95 \%$ and $15 \%$, respectively (an $80 \%$ depth of discharge). The addition of a battery storage to the PV-EV charging station is meant for balancing electricity supply and demand. At each time step of the simulation the energy balance is governed by the following equation:

$$
\mathrm{P}_{\mathrm{pv}}+\mathrm{P}_{\text {battery }}+\mathrm{P}_{\text {grid }}-\mathrm{P}_{\text {demand }}=0
$$

The battery's SOC is calculated at each time step to determine the maximum energy that can be charged or discharged. The reason is that batteries have limitations on the amount of power they absorb or deliver since excessive power can increase thermal losses, decrease overall efficiency and possibly damage equipment. At each time step the charging or discharging power is limited by the rated power selected for the battery:

$$
\begin{aligned}
& \mathrm{P}_{\text {charging }}<\mathrm{P}_{\text {battery,max }} \\
& \mathrm{P}_{\text {discharging }}<\mathrm{P}_{\text {battery,max }}
\end{aligned}
$$

The battery SOC must also be limited to avoid overcharging or deep cycling. At each time step the maximum amounts of energy that can be used to charge or discharge the battery are calculated by [20]: 


$$
\begin{gathered}
E_{\text {max }, \text { lischarge }}=V\left[C-C_{\max } \frac{S O C_{\min }}{100}\right](5) \\
E_{\text {max }, \text { charge }}=V\left[C_{\max } \frac{S O C_{\max }}{100}-C\right](6)
\end{gathered}
$$

where $\mathrm{V}$ is the voltage, $\mathrm{C}$ is the capacity at the last time step in $\mathrm{Ah}, \mathrm{C}_{\max }$ is the rated capacity of the battery and $\mathrm{SOC}_{\min }$ and $\mathrm{SOC}_{\max }$ are the minimum and maximum states of charge in $\%$, respectively. The state of charge therefore always obeys the following constraint at each simulation timestep:

$$
\mathrm{SOC}_{\min } \leq \mathrm{SOC}(\mathrm{t}) \leq \mathrm{SOC}_{\max }
$$

\subsubsection{Performance metrics}

\subsubsection{Self-Consumption rate}

The self-consumption rate (SCR) is defined as the ratio of the energy self-consumed from the PV system ( $\left.E_{S C}\right)$ to the total PV production (EPV) [21]. By adding a battery to the system, the self-consumption can be increased since it stores the excess PV energy and discharges it later when the PV production is not sufficient to meet the load. In this case, the self-consumed energy Esc can be expressed as the sum of the PV energy used directly EPVtoEv and that which comes from the battery $\mathrm{E}_{\text {BatterytoEv: }}$

$$
E_{S C}=E_{P V t o E V}+E_{\text {BatterytoEV }}
$$

The SCR is calculated by the following expression:

$$
\operatorname{SCR} \%=\frac{E_{S C}}{E_{P V}}(8)
$$


From the above equations the energy exported to the grid can be calculated:

$$
\begin{gathered}
E_{\text {exported }}=E_{p v}-E_{S C}(9) \\
E_{\text {exported }}=E_{p v}-S C R^{*} E_{p v}(10) \\
E_{\text {exported }}=E_{p v}(1-S C R)
\end{gathered}
$$

\subsubsection{Self-sufficiency rate}

Similarly, the self-sufficiency rate (SSR) reports how much the self-consumed energy covered the load demand [21]. It is calculated as the ratio of the self-consumed PV energy over the total energy consumption (EEvdemand). This means that the higher the SSR value the higher the degree of independence from the grid. The SSR is calculated by the following expression:

$$
\operatorname{SSR} \%=\frac{E_{S C}}{E_{\text {EVdemand }}}
$$

From the above equation, the amount of energy imported from the grid can be calculated as:

$$
\begin{gathered}
E_{\text {imported }}=E_{E V \text { demand }}-E_{S C}(13) \\
E_{\text {imported }}=E_{E V \text { demand }}-S S R^{*} E_{E V \text { demand }} \\
E_{\text {imported }}=E_{E V \text { demand }}(1-S S R)(15)
\end{gathered}
$$

\subsubsection{Emissions}

The annual energy needs from the proposed charging station are 102,783.93 kWh/year. Considering an average fuel economy of $0.29 \mathrm{kWh} /$ mile for the EV models selected, this amounts to approximately 354,427 miles of travelling distance per year. For the same travelled distance and 
considering a fuel efficiency of 27.9 miles per gallon (MPG) for a gasoline car [22], this would be equivalent to approximately 12,703.5 gallons of fuel consumption per year. According to the EIA [23] the burning of one gallon of gasoline releases $8.9 \mathrm{~kg}_{\text {of }} \mathrm{CO}_{2}$, this will amount to 124.5 of tons of $\mathrm{CO}_{2}$ per year.

In a similar way, the emissions resulting from charging the EVs from the grid can be estimated. For the same distance travelled per year, considering a specific emissions value of $1 \mathrm{~kg}$ $\mathrm{CO}_{2}$ per $\mathrm{kWh}$ for a grid using coal as an energy source [24] , this will amount to 113.5 tons of $\mathrm{CO}_{2}$ per year. It is clear that in terms of emissions, charging EVs from the grid is in fact comparable to a regular gasoline car (only 9.5\% less emissions) hence the interest in using solar.

Considering the case of solar charging, we can calculate the amount of $\mathrm{CO}_{2}$ saved. The interest of using PV with EV charging is to minimize the amount of energy imported from the grid. PV has zero $\mathrm{CO}_{2}$ emissions, however as explained in the previous sections the role of the selfconsumption and self-sufficiency rates is important to know how much solar energy is being used to offset the emissions and how much grid energy was used. The self-consumption rate reflects the amount of PV production that was consumed directly during EV charging and the self-sufficiency rate is the amount of demand covered by the direct use of the solar energy.

Assuming both rates are $100 \%$, this means that all the energy was directly used and all of it was able to offset the demand. In this case, the emissions for the EVs will be zero.

Table 5 illustrates the mileage-based emissions comparison between gasoline vehicles, grid charged EVs and solar charged EVs: 
Table 5: $\mathrm{CO}_{2}$ emissions using gasoline, grid charged EVs and solar charged EVs

\begin{tabular}{|c|c|c|c|}
\hline Property & Gasoline Car & Grid-charged EVs & Solar-charged EVs \\
\hline Travelled distance (miles/year) & 354,427 & 354,427 & 354,427 \\
\hline Fuel economy (MPG or kWh/mile) & 27.9 & 0.29 & 0.29 \\
\hline Fuel consumption (Gallons or kWh) & $12,703.5$ & $102,783.93$ & $102,783.93$ \\
\hline Emissions (kg of $\mathrm{CO}_{2} /$ Gallon or $\left.\mathrm{kWh}\right)$ & 8.9 & 1 & 0 \\
\hline Total emissions (tons of $\mathrm{CO}_{2} /$ year) & 124.5 & 113.6 & 0 \\
\hline
\end{tabular}

The emission reduction from PV can be seen from two perspectives: the first one is on-site emissions, which means the amount of $\mathrm{CO}_{2}$ reduction achieved from directly supplying the charging station with solar electricity. The second way to evaluate emissions is the overall $\mathrm{CO}_{2}$ balance. As explained in the previous sections, the PV satisfies the load first then exports the surplus to the grid which means the exported energy also contributes to reducing emissions even if the energy was not directly used on-site.

In reality, the on-site emissions in the solar charging case will not be offset by $100 \%$, depending on the SSR value. For example, if the SSR value is $50 \%$, that means that half of the energy is still being imported from the grid and therefore only half the of the on-site emissions were reduced. However, part of the energy produced by the PV may have been exported to the grid later, which will count towards the total emission reduction of the PV. The interest in optimizing the PV system design is to eliminate the on-site $\mathrm{CO}_{2}$ emissions without oversizing the system such that it becomes uneconomical. On an annual basis, the on-site $\mathrm{CO}_{2}$ emissions can be calculated as the $\mathrm{CO}_{2}$ avoided when the vehicles are charging [25] :

$$
\Delta \mathrm{CO}_{2} \%(\text { on }- \text { site })=\frac{\mathrm{CO}_{2}(\mathrm{NoPV})-\mathrm{CO}_{2}(\text { with } \mathrm{PV})}{\mathrm{CO}_{2}(\mathrm{NoPV})}
$$

Where the $\mathrm{CO}_{2}$ emissions without $\mathrm{PV}$ is the product of the energy in $\mathrm{kWh}$ and the specific emissions (in $\mathrm{kg}$ of $\mathrm{CO}_{2} / \mathrm{kWh}$ : 


$$
\mathrm{CO}_{2}(\mathrm{NoPV})=\mathrm{CO}_{2 \text { Specific }} * E_{\text {EVdemand }}
$$

And the $\mathrm{CO}_{2}$ emission with PV is the product of the specific emissions and the imported grid energy:

$$
\mathrm{CO}_{2}(\text { with } P V)=C O_{2 \text { Specific }} * E_{\text {imported }}
$$

Combining the expression above, the on-site emission reduction can then be expressed as:

$$
\Delta \mathrm{CO}_{2} \%(\text { on }- \text { site })=\frac{E_{\text {EVdemand }}-E_{\text {imported }}}{E_{\text {EVdemand }}} * 100(19)
$$

Similarly, the total emission reduction can be expressed as the total amount reduced by the PV system. In this case, the total reduction may have a value above $100 \%$ if the total energy produced is larger than the EV energy demand:

$$
\Delta C O_{2} \%(\text { total })=\frac{E_{P V}}{E_{\text {EVdemand }}} * 100(20)
$$

\subsubsection{Input costs and financial parameters}

The following tables list all the cost and financial parameters used in the simulation:

Table 6: PV system costs

\begin{tabular}{|c|c|}
\hline Variable & Value \\
\hline Module cost & $0.35 \$ / \mathrm{Wdc}$ \\
\hline Inverter cost & $0.22 \$ / \mathrm{Wdc}$ \\
\hline Battery cost & $\$ 400 / \mathrm{kWh}$ \\
\hline Balance of system equipment & $0.25 \$ / \mathrm{Wdc}$ \\
\hline Installation labor & $0.12 \$ / \mathrm{Wdc}$ \\
\hline Installer margin and overhead & $0.65 \$ / \mathrm{Wdc}$ \\
\hline Permitting & $0.11 \$ / \mathrm{Wdc}$ \\
\hline Contingency & $3 \%$ of capital cost \\
\hline Operation and maintenance & $\$ 16 / \mathrm{kW}$ \\
\hline
\end{tabular}


Table 7: EVSE costs

\begin{tabular}{|c|c|}
\hline Variable & Value \\
\hline EV charger cost & $\$ 729 /$ unit \\
\hline Installation & $\$ 1,000 /$ unit \\
\hline Operation and maintenance costs & $\$ 400 /$ unit/year \\
\hline
\end{tabular}

Table 8: Financial analysis parameters

\begin{tabular}{|c|c|}
\hline Variable & Value \\
\hline Analysis period & 25 \\
\hline Inflation rate & $2.50 \%$ \\
\hline Real discount rate & $6.40 \%$ \\
\hline Nominal discount rate & $9.06 \%$ \\
\hline Income tax & $21 \%$ \\
\hline Insurance & $0.5 \%$ of system cost \\
\hline PV degradation & $0.5 \% /$ year \\
\hline
\end{tabular}

Table 9: Utility rates (based on Monpower General service 'C' tariff [26])

\begin{tabular}{|c|c|}
\hline Charge & Value \\
\hline Fixed charged & $\$ 40$ \\
\hline Energy charge & 3.588 cents $/ \mathrm{kWh}$ \\
\hline Demand charge & $\$ 15.71 / \mathrm{kWh}$ \\
\hline
\end{tabular}




\subsubsection{Financial metrics}

\subsubsection{Net present value}

The net present value (NPV) is used to evaluate the financial attractiveness of the PV project. The NPV is the sum of the annual differences between the revenues (cash inflows) and expenditures (cash outflows), discounted to the present time.

The cash inflows consist in:

- The investment tax credit (a onetime payment at the beginning of the project).

- The annual energy and demand savings that result from solar charging.

- Net-metering revenue from selling remaining $\mathrm{kWh}$ credits at the end of each year.

- Annual revenue from selling SRECs.

The cash outflows consist in:

- Investment costs (a onetime expenditure at the beginning of the project).

- Annual operation and maintenance costs.

- Annual insurance and income taxes.

Because of PV cell degradation, the energy savings decrease over time. To account for this, the degradation of PV cell is also included in the calculation of the NPV in SAM. For this research a $0.5 \%$ annual degradation was assumed.

If the NPV of the project is positive, it means that the revenues offset the initial and ongoing expenditures associated with operating the system and the project is financially attractive. A negative NPV means that the by the end of the project lifetime, the costs are more than the benefits.

The NPV is calculated by the following expression: 


$$
N P V=\sum_{n=0}^{N} \frac{C F_{n e t}}{\left(1-d_{n o \min a l}\right)^{n}}
$$

where $\mathrm{CF}_{\text {net }}$ is the net cashflow, $\mathrm{d}_{\text {nominal }}$ is the nominal discount rate and $\mathrm{N}$ is the project period.

\subsubsection{Simple payback period}

The PV system generates savings by avoiding the electricity charges associated with charging the EV from the grid. In this case, the payback period (PBP) can be defined as the number of years it takes the project net cashflow to offset the initial investment costs of the PV system. The PBP can also be defined as the time it takes for the NPV to become zero or greater. The shorter the payback period, the sooner it takes for the project to become profitable. Typically, a payback less than 15 years for PV is considered an attractive investment. If the payback is more than the lifetime of the project the system is not considered. The PBP is expressed as:

$$
P B P(\text { years })=\frac{\text { Investment costs }}{\text { Annual savings }- \text { Annual operating costs }}(22)
$$

The PBP of the project can also be evaluated by comparing the savings from the EV charging scenarios with gasoline vehicles operating for the same annual mileage. In this case, the cash inflows can be defined as the fuel savings associated with EV charging instead of operating a fleet of gasoline vehicles. For example, if we consider an average gasoline price of $\$ 2.35 /$ gallon in West Virginia [27], an annual travelled distance of 354,427 miles and a gasoline fuel economy of 27.9 MPG, the yearly gasoline fuel costs will be $\$ 29,853 /$ year. In the case of EVs being charged from PV, considering an energy generation cost of 10 cents/kWh and assuming the vehicles are entirely charged with solar, the annual fuel costs are $\$ 10,287 /$ year. The annual savings are the difference in fuel costs between gasoline and PV charging which amounts to $\$ 19,266.225 /$ year. Accounting for annual maintenance and operating cost of PV, the payback period is 11 years. 
The comparison is summarized in Table 10:

Table 10: PV-EV versus gasoline vehicles

\begin{tabular}{|c|c|c|}
\hline Property & Gasoline car & PV-EV \\
\hline Annual travelled distance & 354,427 & 354,427 \\
\hline Fuel economy (MPG or kWh/mile) & 27.9 & 0.29 \\
\hline Annual energy required (gallons or kWh) & $12,703.5$ & $102,783.93$ \\
\hline Fuel cost (\$/Gallon or \$/kWh) & 2.35 & 0.10 \\
\hline Annual fuel cost (\$) & $29,853.225$ & 10,287 \\
\hline Fuel cost (\$/mile) & 0.084 & 0.03 \\
\hline Annual fuel savings (\$/year) & 0 & $19,266.225$ \\
\hline Annual operating costs (\$/year) & 0 & 161,264 \\
\hline Investment cost $\$$ ) & - & $481,656.375$ \\
\hline Total savings for 25 year $(\$)$ & - & 11 \\
\hline Payback period (years) & - & \\
\hline
\end{tabular}

\subsubsection{SREC pricing}

The baseline price for selling the SRECs is set to the latest bid of $8.5 \$$ SREC in the Ohio market. These prices can vary considerably throughout the year. Figure 10 shows the fluctuation of the SREC price during the last two years.

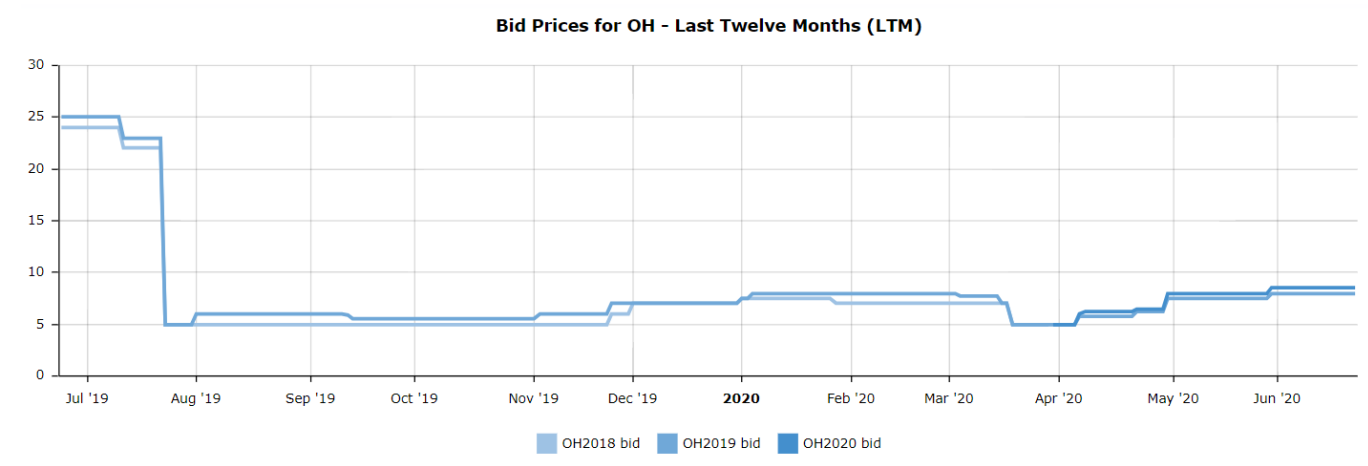

Figure 10: SREC market bids fluctuation [13] 


\section{RESULTS AND DISCUSSION}

\subsection{Reference case: PV system without energy storage}

\subsubsection{Analysis of system performance}

Figure 11 shows the hourly production profile of the PV system versus the load demand at each hour of the first week in January (top) and May (bottom). It can be seen that both profiles vary considerably from day-to-day. The sample week in January shows that even under low irradiance, the $100 \mathrm{~kW}$ system can cover the energy needs of the proposed charging station and reduce its peak demand most of the time, confirming the assumption that PV can be a reliable way to power EV charging stations even with variability in the production profile. In the sunniest periods of the year, the system generates surplus electricity and exports energy into the grid. The proportion of self-consumed energy and degree of grid independence can be understood further by looking at the monthly self-consumption (SCR) and self-sufficiency rates (SSR) of the installation in Figure 12. For example, an SCR of $67 \%$ in January means that $67 \%$ of the energy that was produced was consumed on-site by the charging station and the rest was exported to the grid. At the same time, the SSR had a value of $49 \%$ meaning that almost half of the demand was covered by PV output and the other half was imported from the grid. Over the entire year, the PV system produced $129,300 \mathrm{kWh}$, exported 54,007kWh to the grid and imported 27,956kWh from the grid. These values translate into an annual SSR of $72 \%$ and an SCR of 58\%. 82.7 tons of $\mathrm{CO}_{2}$ were reduced on-site (72\% reduction). This reduction corresponds to the amount avoided by directly supplying EVs with solar energy. Given that the system exports more energy into the grid, the total amount of emissions reduced was 143 tons of $\mathrm{CO}_{2}$, which is more than the $\mathrm{CO}_{2}$ emissions of the charging station. 
Hourly load profile (kW) $\quad$ PV hourly output $(k W)$

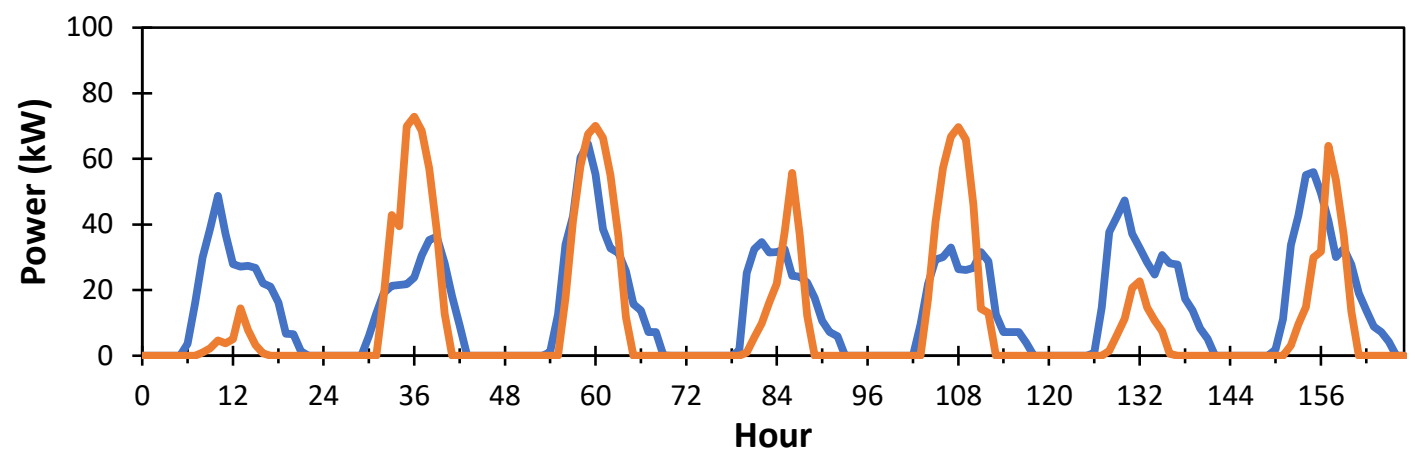

Hourly load profile (kW) $\longrightarrow$ PV hourly output (kW)

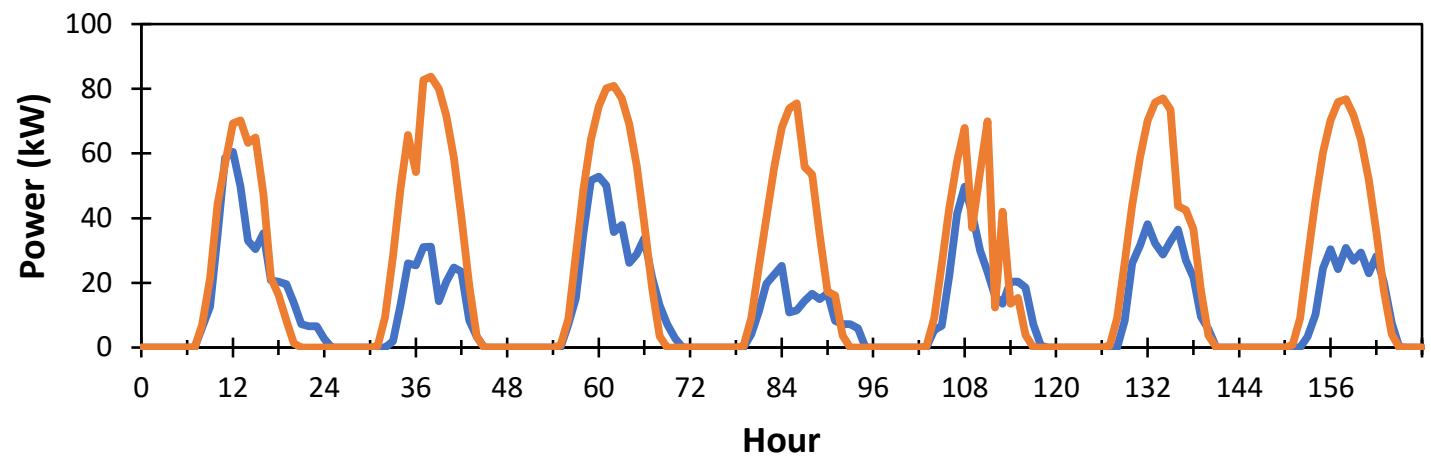

Figure 11: Hourly PV output and charging station load demand for sample weeks in January (top) and May (bottom).
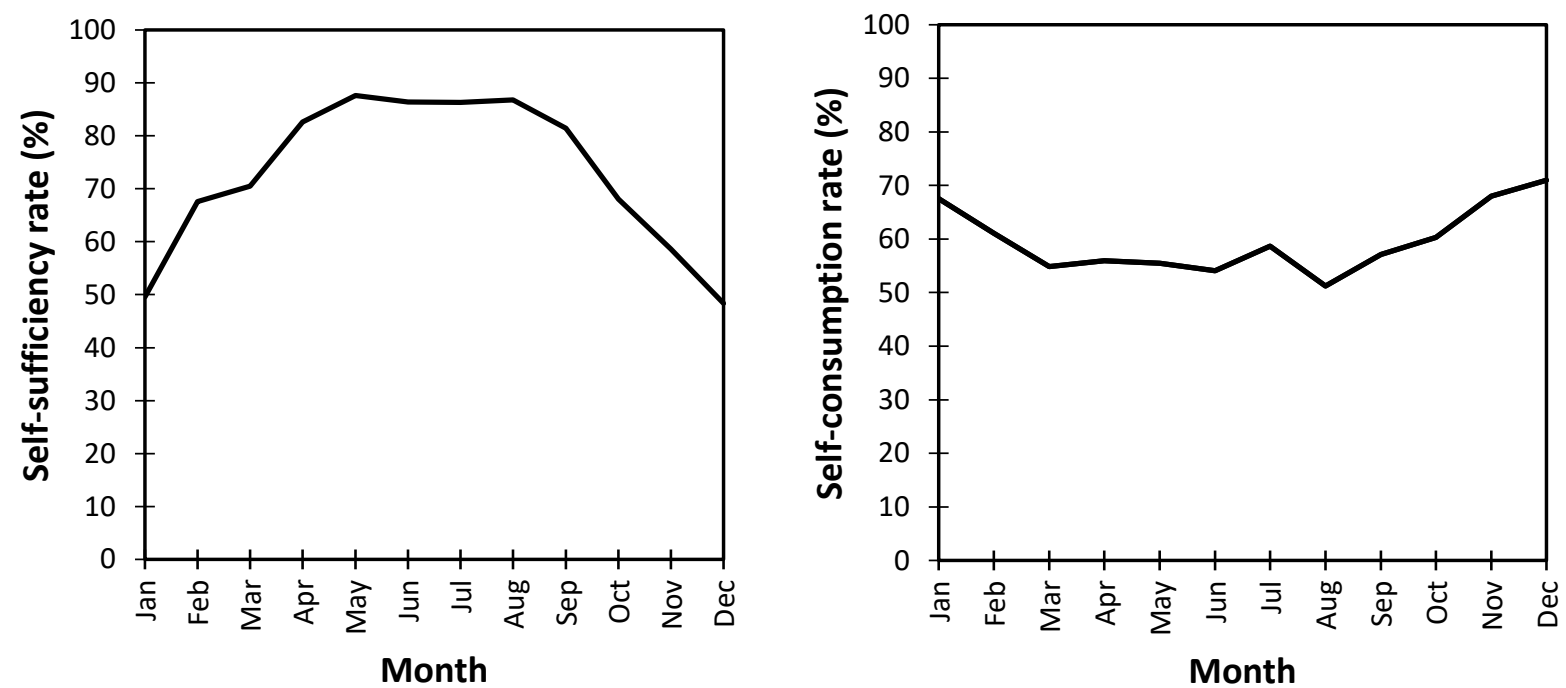

Figure 12: Monthly self-consumption and self-sufficiency rates 
Figure 13 shows the monthly peak demand reduction by the PV system. Peak demand is effectively reduced by the PV system in each month by up to $35 \mathrm{~kW}$ in April. Overall energy charges were reduced by $\$ 4,618.57$ and demand charges by $\$ 3602.15$, a total of $\$ 8,221$ of savings per year on the electricity bill.

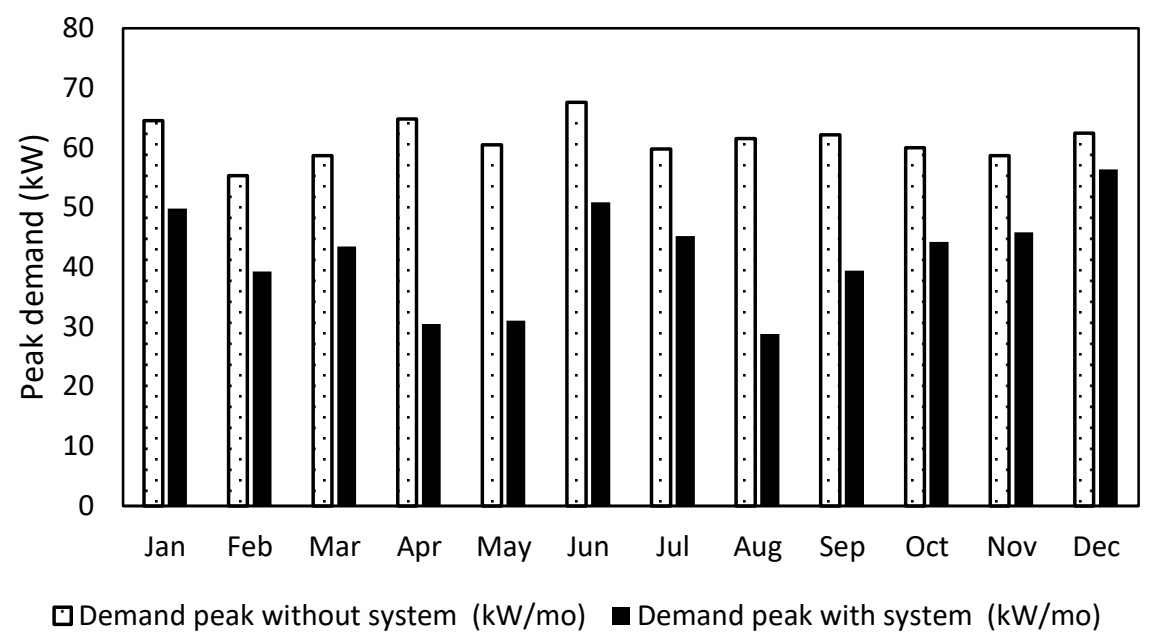

Figure 13: Peak demand reduction with 100kW PV system

The system also generates revenue through net-metering by selling the cumulated energy credits at the end of the year. Every month, the system injects the excess electricity which is the difference between the production and the load in that month (Figure 14). In each month, if the production exceeds the load, the excess injected into the grid is cumulated with the amount from the previous month. If the load exceeds the production, the electricity used from the grid is compensated by the $\mathrm{kWh}$ credits already earned in previous months. In total, a $\$ 1,021$ revenue was generated through net-metering. 


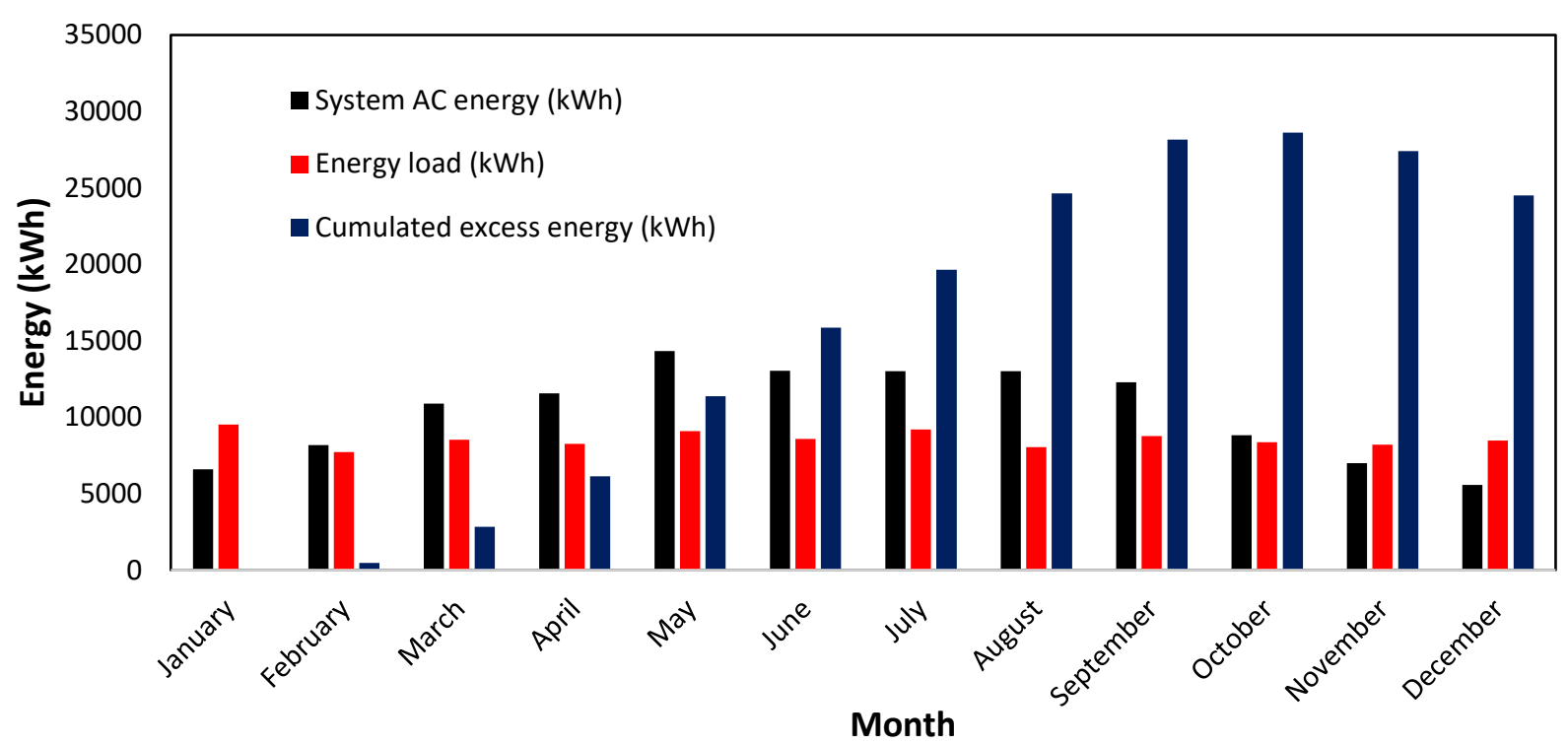

Figure 14: Monthly PV production, electricity load and excess energy

Additionally, the system generates revenue from trading SCREs. With an energy production of about $129 \mathrm{MWh}, 129$ SRECs were sold at a price of $\$ 8.5 / \mathrm{SREC}$ adding a total revenue of $\$ 1,096.5$. Considering an investment tax credit (ITC) of $26 \%$, the net present value amounted to $-\$ 85,617$ with a simple payback period of 24 years. It is clear that despite the electricity savings and the significant $\mathrm{CO}_{2}$ reductions, the system is not financially attractive since it has a negative NPV.

\subsection{Sensitivity analysis for the PV only case}

\subsubsection{System capacity}

Three system sizes were compared in this sensitivity analysis: $50 \mathrm{~kW}, 75 \mathrm{~kW}$ and $100 \mathrm{~kW}$. All other financial input parameters were kept constant. The results are summarized in the Table 11: 
Table 11: Summary of PV system performance for different array sizes

\begin{tabular}{|l|c|c|c|}
\hline \multicolumn{1}{|c|}{ Parameter } & System 1 & System 2 & System 3 \\
\hline PV system size & $50 \mathrm{~kW}$ & $75 \mathrm{~kW}$ & $100 \mathrm{~kW}$ \\
\hline Energy yield (kWh/year) & $64,570.80$ & $96,998.74$ & $129,300.60$ \\
\hline Energy imported from the grid $(\mathrm{kWh})$ & $45,942.60$ & $345,91.3$ & $27,956.30$ \\
\hline Energy exported to the grid $(\mathrm{kWh})$ & 9878 & 27,264 & $54,007.80$ \\
\hline Self-consumed energy $(\mathrm{kWh})$ & 56841.3 & 68192.62 & 74827.6 \\
\hline Annual self-consumption rate $(\%)$ & 88 & 70.3 & 58 \\
\hline Annual self-sufficiency rate $(\%)$ & 55 & 66 & 72 \\
\hline Electricity bill savings (\$) & 5120.8 & 6580.42 & 8220.84 \\
\hline Net Present Value $(\$)$ & $-36,887.6$ & $-59,173.3$ & $-85,617.4$ \\
\hline Simple Payback Period (years) & 19.3 & 21.9 & 24 \\
\hline Cost of energy (\$/kWh) & 0.0987 & 0.0985 & 0.0985 \\
\hline $\mathrm{CO}_{2}$ reduced on-site (tons) & 62.8 & 75.4 & 82.7 \\
\hline $\mathrm{CO}_{2}$ reduced on-site $(\%)$ & 55 & 66 & 72 \\
\hline Total $\mathrm{CO}_{2}$ reduced (tons) & 71 & 107 & 143 \\
\hline Total $\mathrm{CO}_{2}$ reduction $(\%)$ & 57 & 86.3 & 115 \\
\hline
\end{tabular}

Results from varying the PV system size show that decreasing the system size increases the amount of energy imported from the grid and decreases the energy exports. This is also reflected in the SCR and SSR values. By decreasing the system size, a larger portion of the energy produced is self-consumed. The SCR increases from 58\% for the $100 \mathrm{~kW}$ PV system to $88 \%$ for the 50kW system. On the other hand, the SSR values follow the opposite trend. By reducing the system size, the EVCS relies more on the grid, the SSR decreases from $72 \%$ in the case of the $100 \mathrm{~kW}$ PV system to $55 \%$ for the $50 \mathrm{~kW}$ system. This is also reflected in the amount of on-site emissions reduced: the $50 \mathrm{~kW}$ system reduces on-site emissions by $55 \%$ compared to $72 \%$ for the $100 \mathrm{~kW}$ system. Moreover, it can be seen that superior SSR values result in increased on-site and total emission reduction but also lower NPVs. Decreasing the system size to $50 \mathrm{~kW}$ resulted in the highest net present value. However, it is still negative making the project financially infeasible. 


\subsubsection{Cost per installed capacity}

The analysis for the reference case was calculated assuming an installed cost of $\$ 1.83 /$ Watt according to NREL's 2018 cost benchmark for PV installations in the U.S [28] . The module price was set to $35 \mathrm{cents} /$ and 22 cents/Watt for the inverter. Figure 15 shows the impact of price variation on the net present value. A decline by 50\% in the PV module and inverter price can increase the NPV by $17.5 \%$ and $11.6 \%$ respectively. In both cases however, the NPV remains negative and the project is not financially viable.

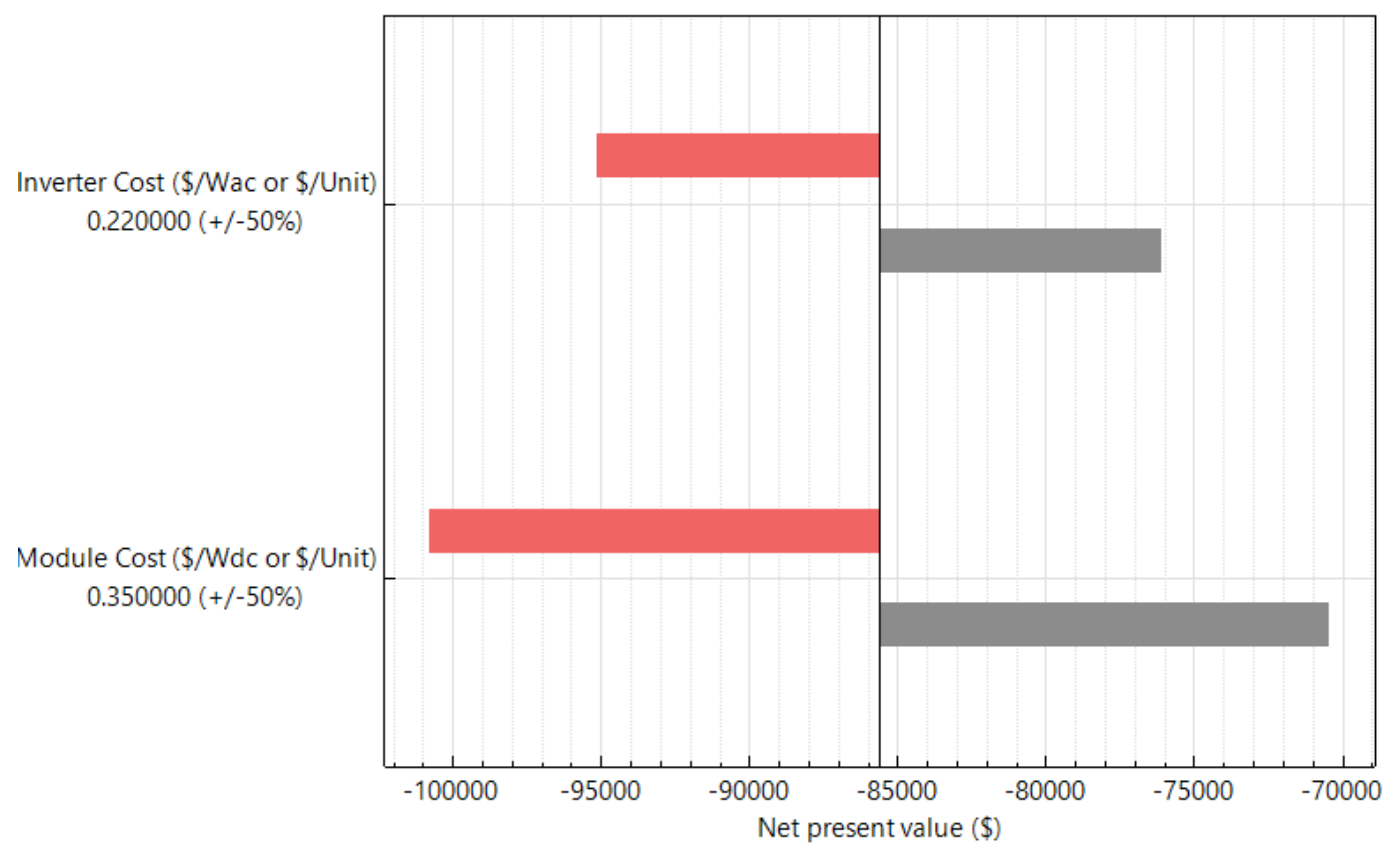

$(--) \square(++)$

Figure 15: Installation cost sensitivity analysis

\subsubsection{Solar renewable energy credit price}

SRECs constitute an additional value stream for the project that can make it highly profitable depending on the market prices. One SREC is earned for every MWh generated by the 
solar PV system. In states that have a Renewable Portfolio Standard (RPS), utilities must buy SRECs to provide proof that RPS goals are being met. SRECs can also be sold to private companies like Google and Amazon who use them to meet corporate sustainability goals and offset their carbon footprint. Since West Virginia doesn't have an RPS, SRECs in the state have no value, however PV system owners in WV can still trade their SRECs in the Ohio market. For this simulation, the most recent bid price for SRECs in the Ohio market was set to $8.5 \$$ /SREC as of 2020. According to SRECtrade [13] prices in Ohio fluctuated between $5 \$$ and $25 \$$ between 2018 and 2020. The impact of varying SREC prices in this range on the feasibility of the project can be seen in Figure 16. For example, at a SREC price of $25 \$$ the NPV increases by about $\$ 12,000$ (14\%) compared to the reference case. This however doesn't have much impact on the feasibility of the project because of the low SREC price. In other states such as Massachusetts and New Jersey for example SRECs can be traded for as high as $\$ 300$. Figure 17 shows how the system can make profits by selling SRECs in high demand markets or to large corporations. The prices were varied between $\$ 10 / \mathrm{MWh}$ and $\$ 300 / \mathrm{MWh}$. The project reaches the break-even point at a price cap of $\$ 100 / \mathrm{MWh}$. At a price of $\$ 300 / \mathrm{MWh}$ the system generates close to $\$ 200,000$ in profit with a payback period of less than 5 years (Figure 18). 


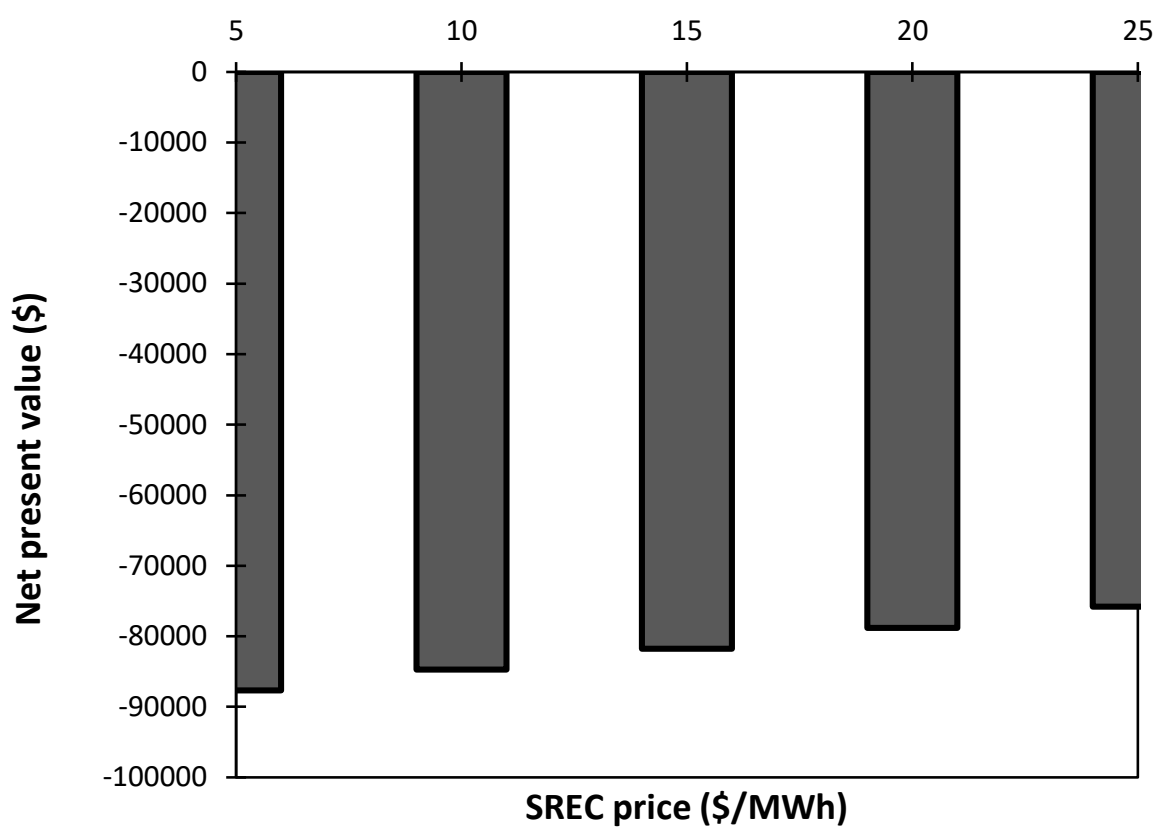

Figure 16: Variation of the net present value with SREC prices in Ohio

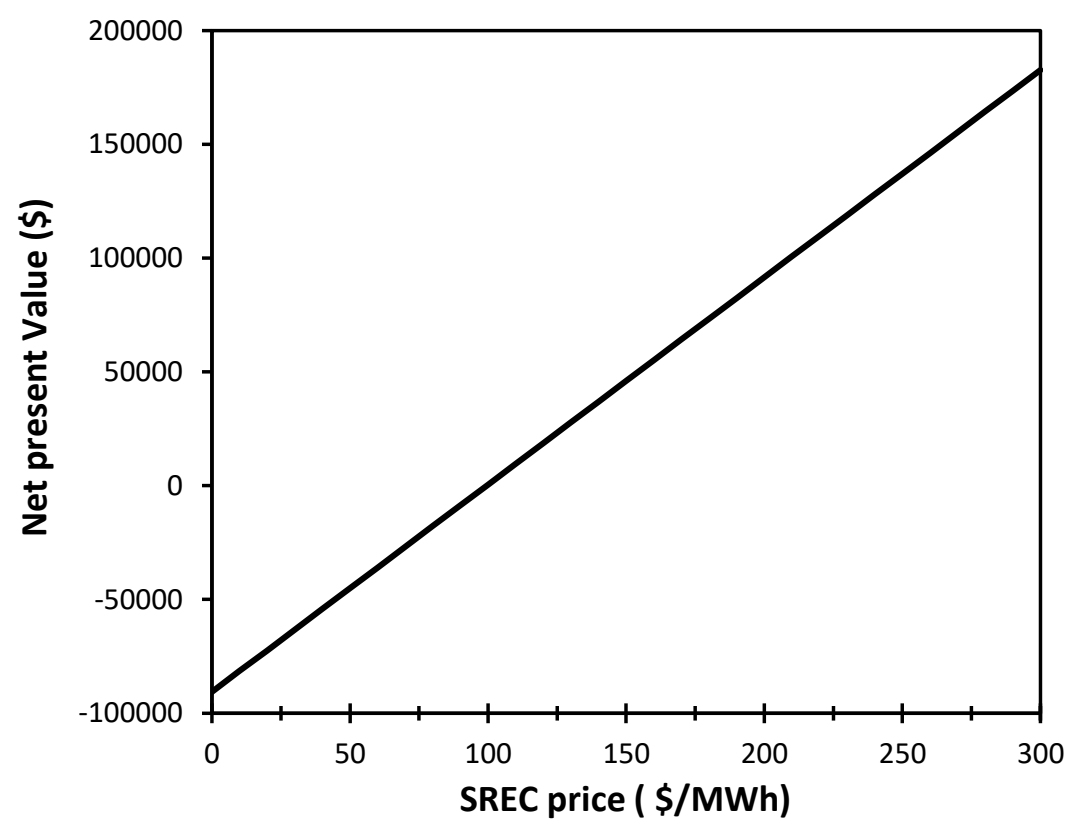

Figure 17: Variation of the net present value with SREC prices 


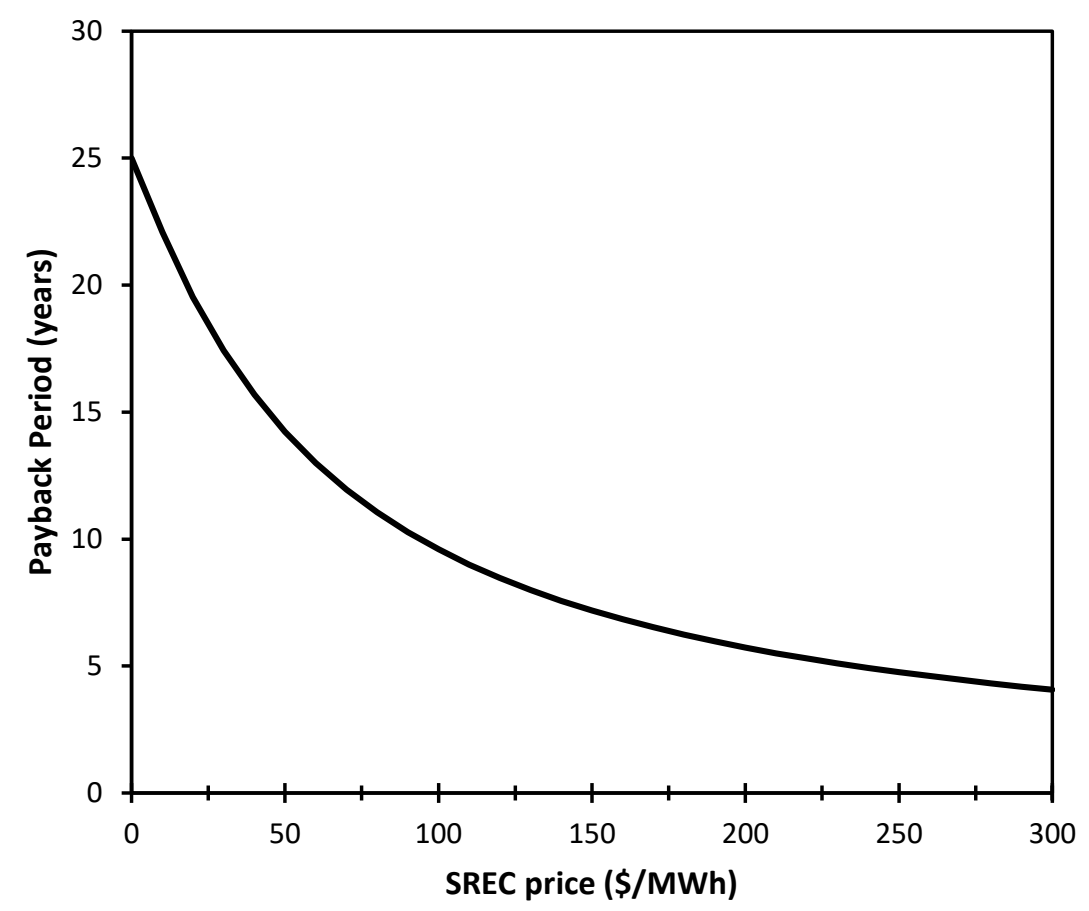

Figure 18: Variation of the simple payback period with SREC prices

\subsubsection{Electricity price growth rate}

The reference case assumed an energy charge of $3.58 \mathrm{cents} / \mathrm{kWh}$ and a demand charge of $\$ 15.571 / \mathrm{kW}$, with no annual escalation rate. The escalation rate analysis considers the expected electricity price inflation over the lifetime of the PV project (25 years). As electricity becomes more expensive, the PV system should yield more savings over the years. In this scenario, the escalation was varied from $0 \%$ (reference) to $2.5 \%$ with $0.5 \%$ increments. As shown in Figure 19 the impact on the net present value is not significant, as in the most aggressive scenario $(2.5 \%$ escalation rate), the NPV increases by $\$ 17,593$ (20\%) and remains negative. This can be attributed to the fact that savings will occur in the far future where they are heavily discounted and therefore do not impact the NPV as much. 


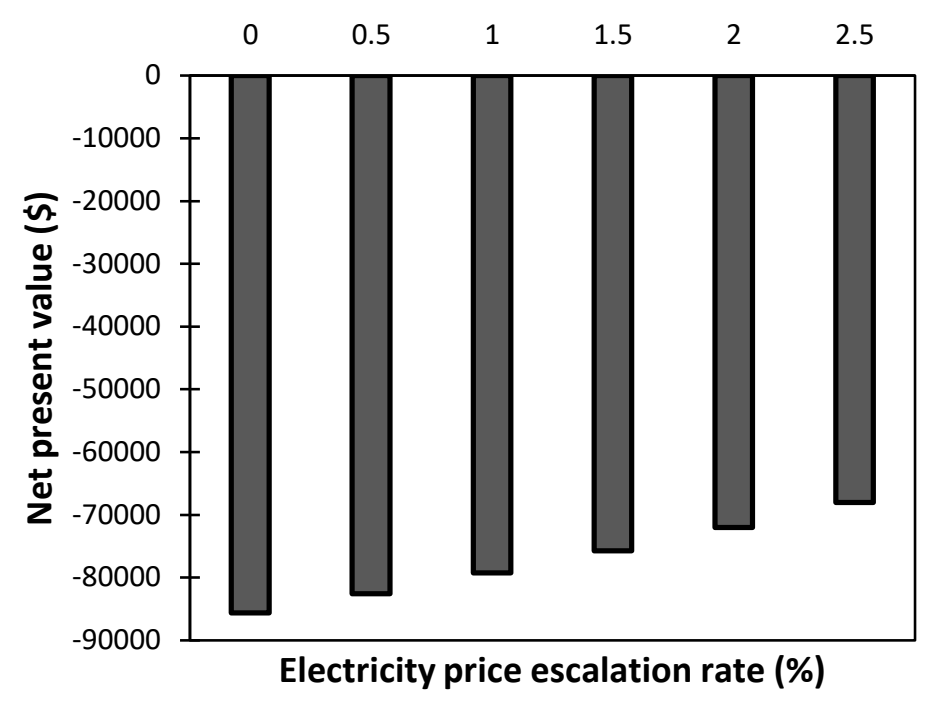

Figure 19: Variation of the net present value with electricity escalation rate

\subsubsection{Third-party ownership}

As discussed in the previous scenarios, the financial model assumed was a direct ownership of the system. Even with the investment tax credit, net-metering and SREC trading scenarios, the project remains financially unattractive with a negative NPV. In this analysis the third-party ownership, i.e the PPA is evaluated to check its financial implications. Although currently PPAs are not offered in West Virginia, it is interesting to analyze how implementing them would affect the feasibility of the solar project. In the PPA financial model, there are no upfront costs, the PV system is owned by the system developer and the beneficiary (customer) of the system pays a fixed rate called the PPA price. This scenario is calculated from the perspective of the customer and it is assumed that the latter retains ownership of the generated SRECs. PPA pricing can vary depending on the state, the solar developer and the terms of the PPA. To determine at which price level a PPA becomes financially attractive option for this system in WV, the NPV is calculated for a range of PPA prices from 4 cents/kWh to 12 cents/kWh which is an average range for commercial 
PV installations across the U.S. The annual escalation rate for the PPA price is set to 1\%/year. As shown in Figure 20, the PPA pricing can determine whether the project is financially attractive or not. Locking the PPA price below 7 cent/kWh results in a positive NPV and the project becomes financially feasible.

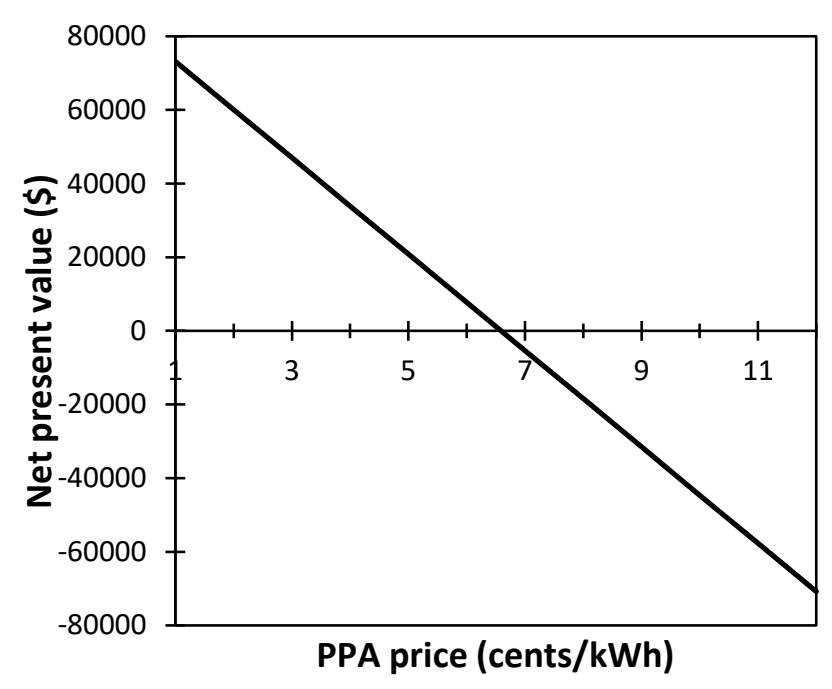

Figure 20: Variation of net present value with the PPA price (cents/kWh)

\subsection{System 2: PV system with battery storage}

So far, it was shown that the only way to make the project profitable (positive NPV) is to sell SRECs at a price of $\$ 100 / \mathrm{MWh}$ or use a PPA with a price below 7 cents $/ \mathrm{kWh}$. In this second analysis, all the financial parameters are re-set to default, and we are interested in studying the financial and environmental implications of adding battery storage. The simulations are performed in SAM using the 100kW PV system from the reference case with the addition of a 500V, 100 $\mathrm{kWh} / 25 \mathrm{~kW}$ lithium-ion battery. 


\subsubsection{Analysis of system performance}

Figure 21 shows the hourly power flows from the PV panels, battery and grid for a sample day in May. As expected, the PV system charges the batteries when excess is available (for example from 8am to 10am) and exports power to the grid whenever excess is available, but the battery is fully charged (from $12 \mathrm{am}$ to $5 \mathrm{pm}$ ). The battery intervenes to reduce the evening peak demand when the PV system output is not enough (5pm to midnight). Results in Figure 23 show the effectiveness of the battery in reducing monthly peak demand. For example, up to 40kW was reduced in May compared to $35 \mathrm{~kW}$ in the PV only case, and overall electricity charges were reduced by $63 \%$. The addition of the battery also increased the self-consumption rate to $64 \%$ and the self-sufficiency to $81 \%$ (compared to $58 \%$ and $72 \%$ in the reference case). This highlights the role of the battery in maximizing the use of surplus PV and decreasing reliance on the grid.

The system saves $\$ 9,933$ in energy and demand charges (20\% more bill savings compared to the case with PV only). However, the net present value is still negative at $-\$ 104,117$ which is lower than the no battery case meaning that the bill savings do not offset the added cost of the battery. It is evident that the addition of a storage battery has some benefits in maximizing the use of PV when EVs are charging and reducing peak demand when PV is not available. However, the NPV may be further optimized by varying capacity bank size along with the PV array size. 


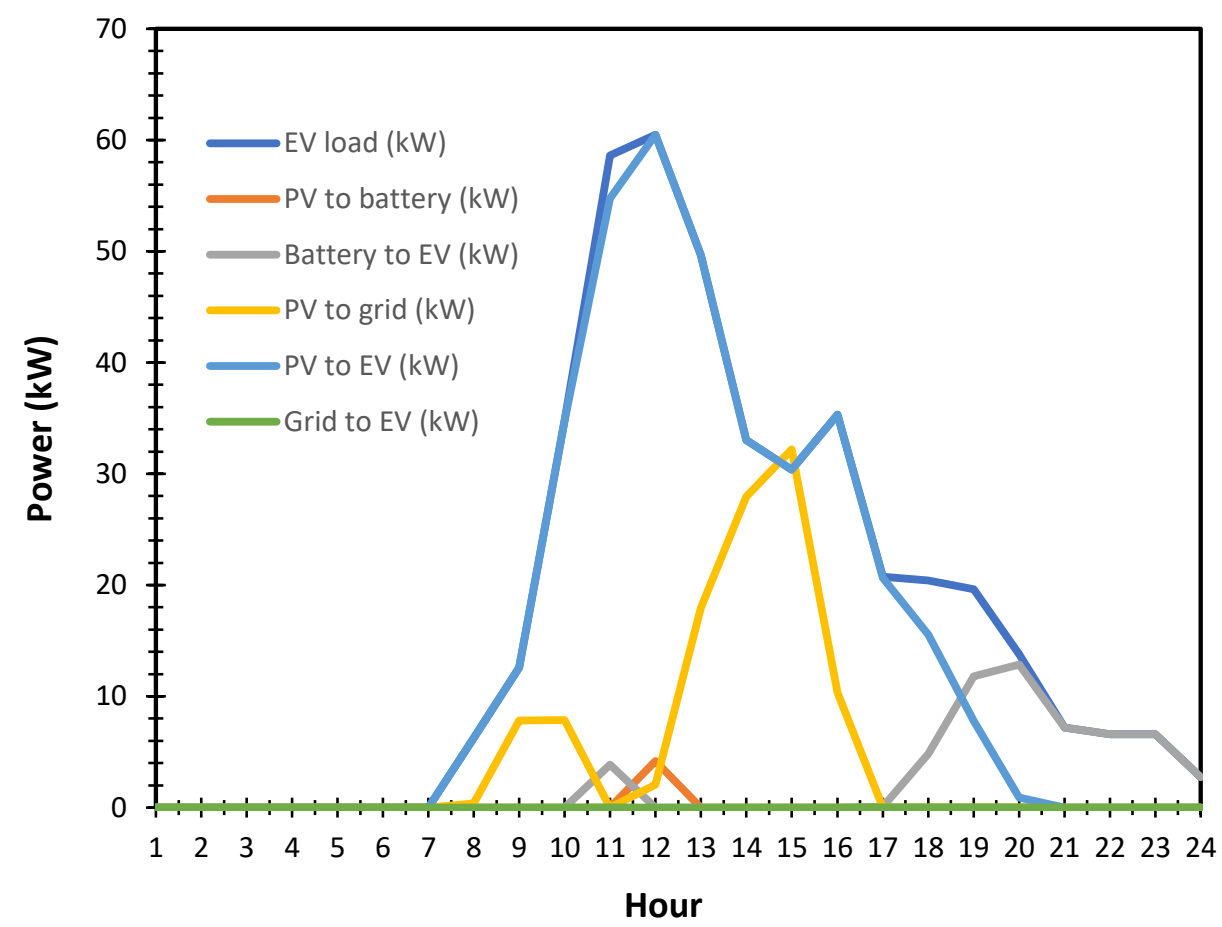

Figure 21: Power dispatch for the PV+storage system for a sample day in May

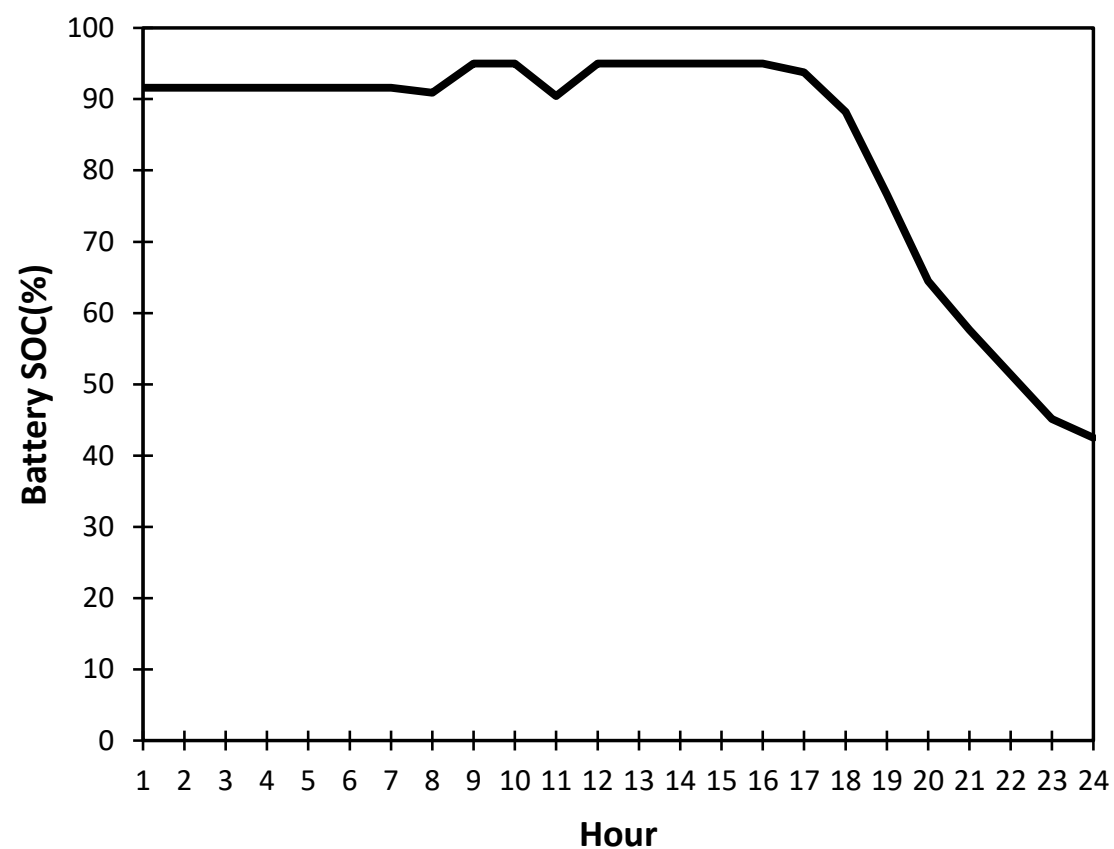

Figure 22: Daily variation of battery state of charge 


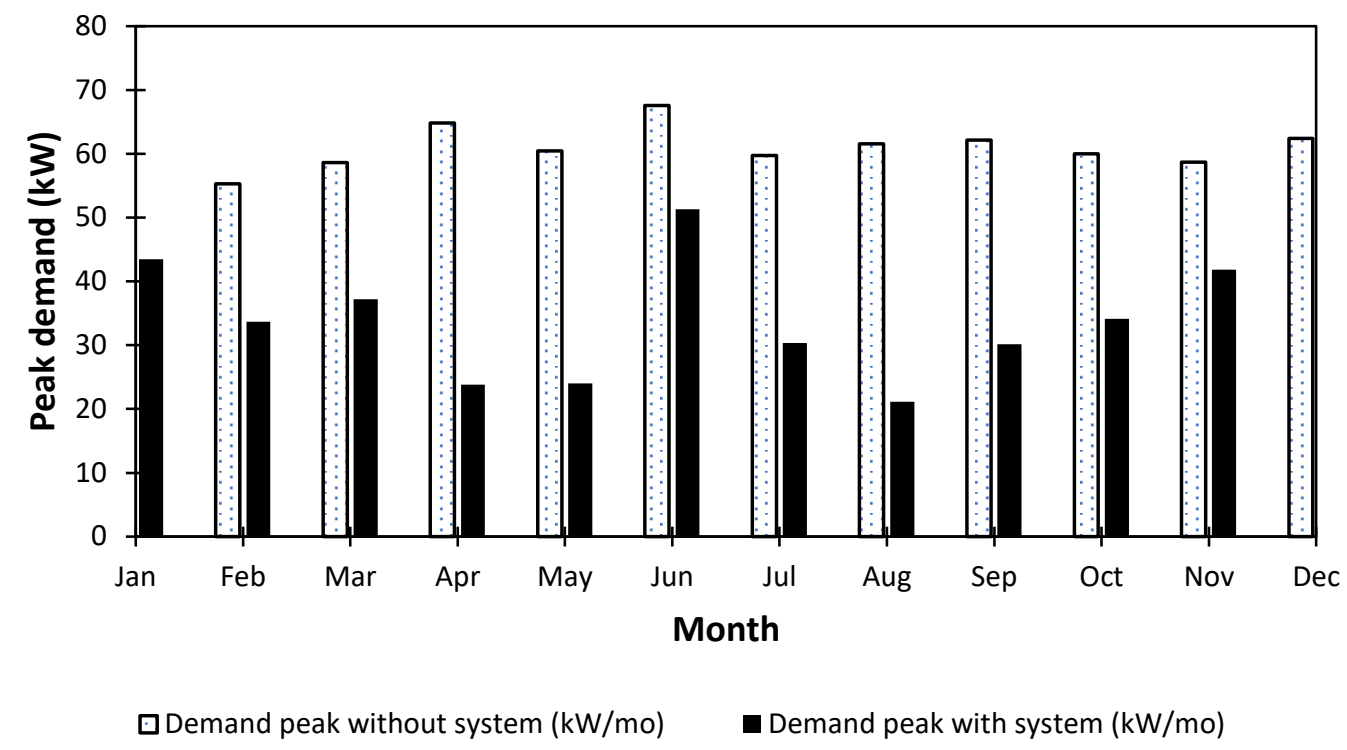

Figure 23: Peak demand reduction for the PV+battery case

\subsection{Sensitivity analysis for the PV with storage case}

\subsubsection{Battery and PV system size}

To examine the financial and environmental implications of differently sized battery banks, the battery size was varied from 0 to $150 \mathrm{kWh}$ with increments of $25 \mathrm{kWh}$, and three PV system sizes were considered: 50kW, $75 \mathrm{~kW}$ and $100 \mathrm{~kW}$. Figures 24,25 and 26 show the variation of the NPV, SSR and SCR with PV and battery system size. 


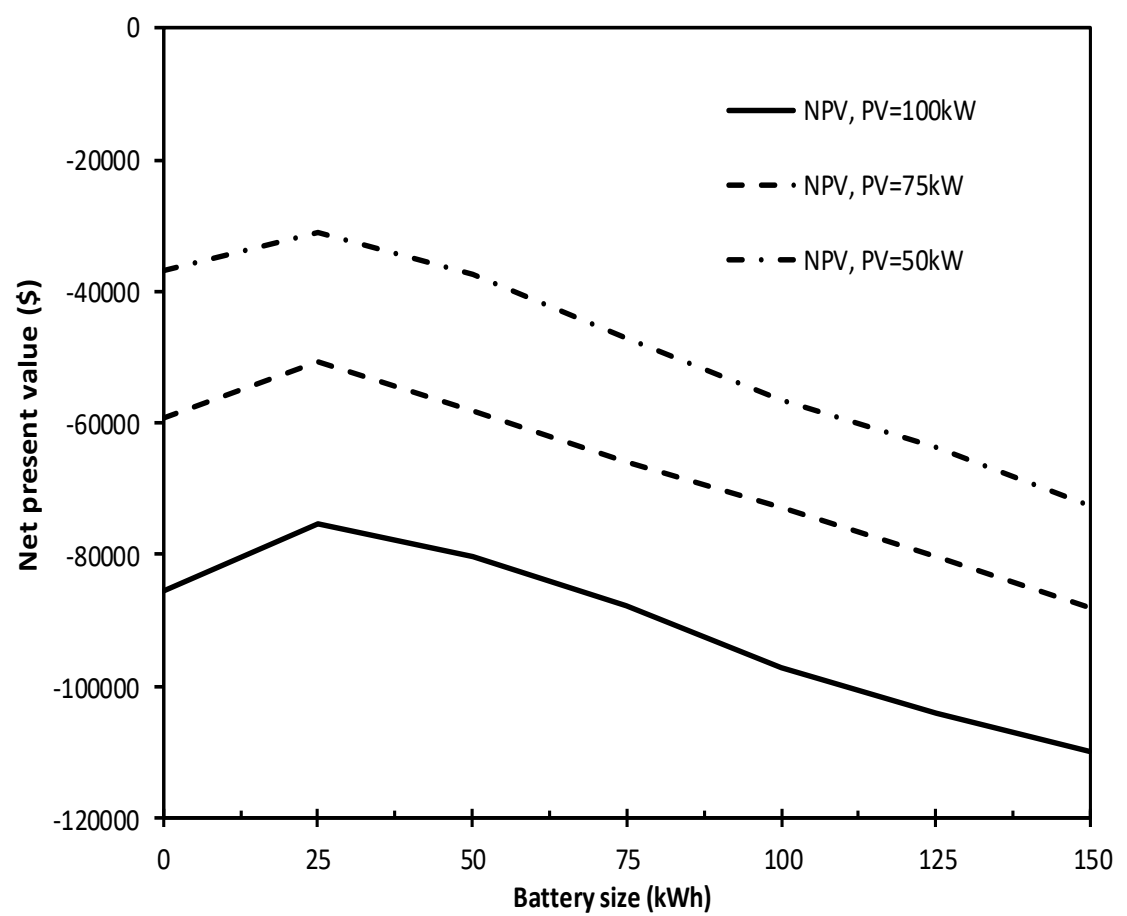

Figure 24: NPV with varying PV system and battery size

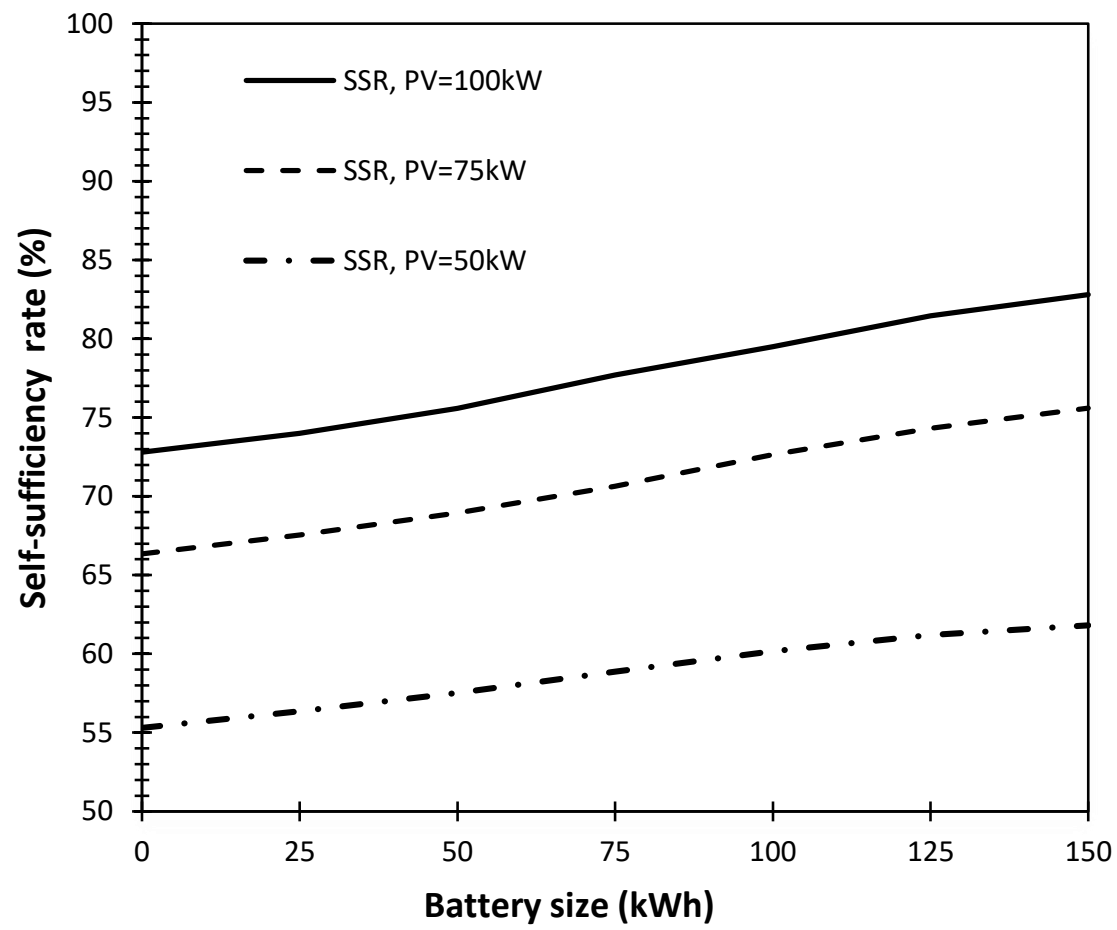

Figure 25: Variation of the self-sufficiency rate with PV and battery size 


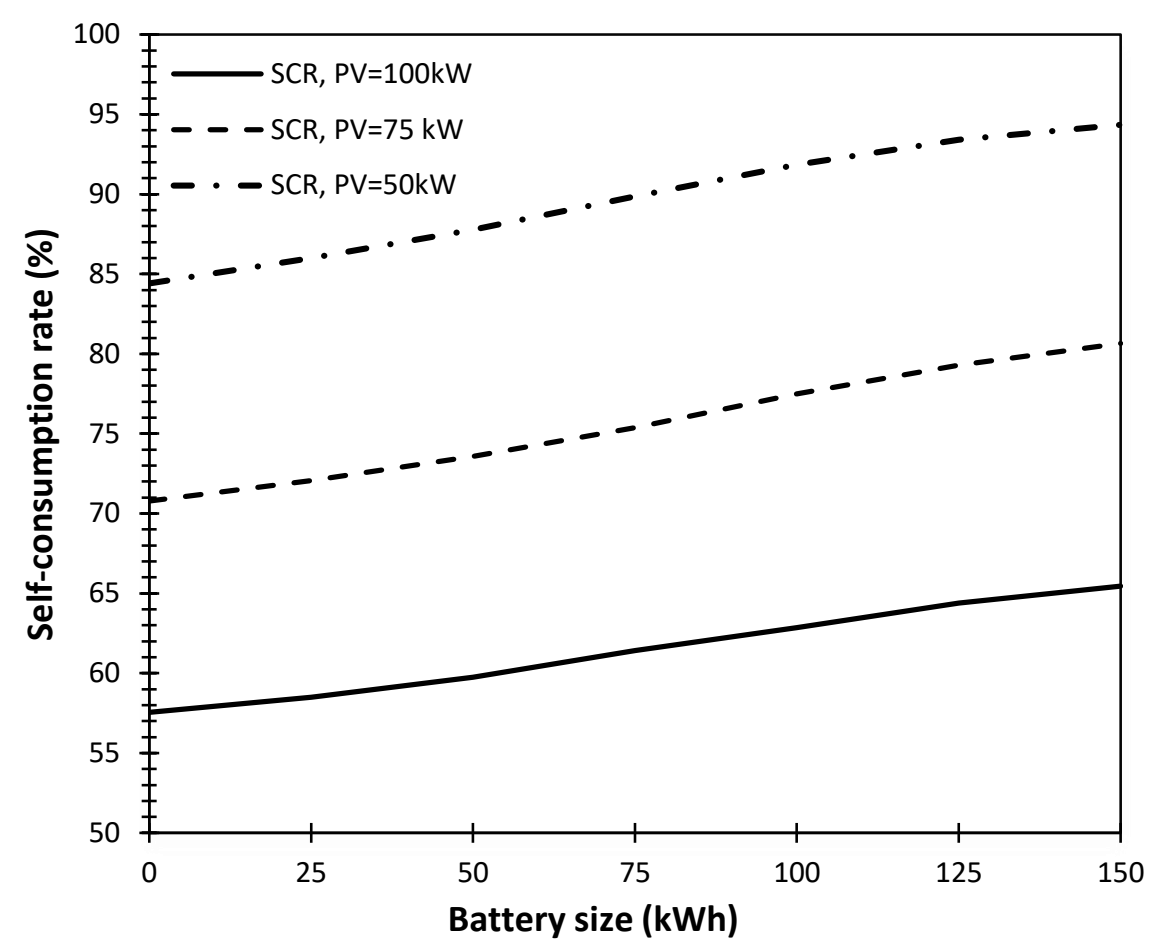

Figure 26: Variation of the self-consumption rate with PV and battery size

It is clear from Figure 24 that increasing the battery capacity up to $25 \mathrm{kWh}$ results in an improvement in the net present value for all PV system sizes. However, beyond $25 \mathrm{kWh}$ the additional battery cost becomes greater than the electricity bill savings. However, in all cases considered the NPV remains negative. Furthermore, as seen in Figure 25, increasing the battery size from 0 to $150 \mathrm{kWh}$ also increases SSR values for all system sizes considered which means that on-site $\mathrm{CO}_{2}$ emissions are also increased because the battery maximizes the use of the surplus PV electricity.

Combining these results, it can be deduced that properly sizing the PV array and battery can positively impact the profitability of the system without significantly undermining emission reduction. For example, with a $75 \mathrm{~kW}$ PV system, adding a $25 \mathrm{kWh}$ battery results in an NPV of - 
$\$ 50,801$ which is higher compared to a $100 \mathrm{~kW}$ PV system with no battery which has an NPV of $\$ 85,617$. This is a $40 \%$ increase in the NPV which is significant even though both systems still have negative NPVs. On the other hand, the $75 \mathrm{~kW}$ PV/ $25 \mathrm{kWh}$ battery system reduces on-site emissions by $68 \%$ compared to $72 \%$, a difference of only $4 \%$.

Table 12: Summary of PV system performances with the battery

\begin{tabular}{|c|c|c|c|}
\hline Parameter & System 1 & System 2 & System 3 \\
\hline PV size (kW) & 50 & 75 & 100 \\
\hline Battery size (kWh) & 25 & 25 & 25 \\
\hline Annual Yield (kWh) & $64,432.8$ & $9,6834.8$ & $129,140.4$ \\
\hline Energy from the grid (kWh) & 44,868 & 33,369 & 26,714 \\
\hline Energy to the grid (kWh) & $8,640.9$ & 25,882 & $52,606.5$ \\
\hline Self-consumed energy (kWh) & 57,915 & 69,414 & $76,069.37$ \\
\hline Self-consumption rate (SCR \%) & 86 & 72 & 58.5 \\
\hline Self-sufficiency rate (SSR \%) & 56 & 68 & 74 \\
\hline Electricity bill savings (\$/year) & 6,621 & 8408.5 & $-75,222$ \\
\hline $\mathrm{Net}_{\text {present Value (\$) }}$ & $-31,051$ & $-50,801.60$ & 19.9 \\
\hline Simple payback period (years) & 15.95 & 17.8 & 74.33 \\
\hline On-site $\mathrm{CO}_{2}$ emissions reduced (tons) & 64 & 76.7 & 143 \\
\hline On-site $\mathrm{CO}_{2}$ emissions reduced (\%) & 56 & 68 & 107 \\
\hline Total $\mathrm{CO}_{2}$ emissions reduced (tons) & 71 & 86 & \\
\hline Total $\mathrm{CO}_{2}$ emissions reduced (\%) & 57 & & 107 \\
\hline
\end{tabular}




\subsubsection{Battery cost}

Taking the optimal case of a $50 \mathrm{~kW}$ and $25 \mathrm{kWh}$ battery in terms of NPV, we evaluate the impact of battery cost on the feasibility considering a battery price between $\$ 150 / \mathrm{kWh}$ and $\$ 650 / \mathrm{kWh}$ (Figure 27).

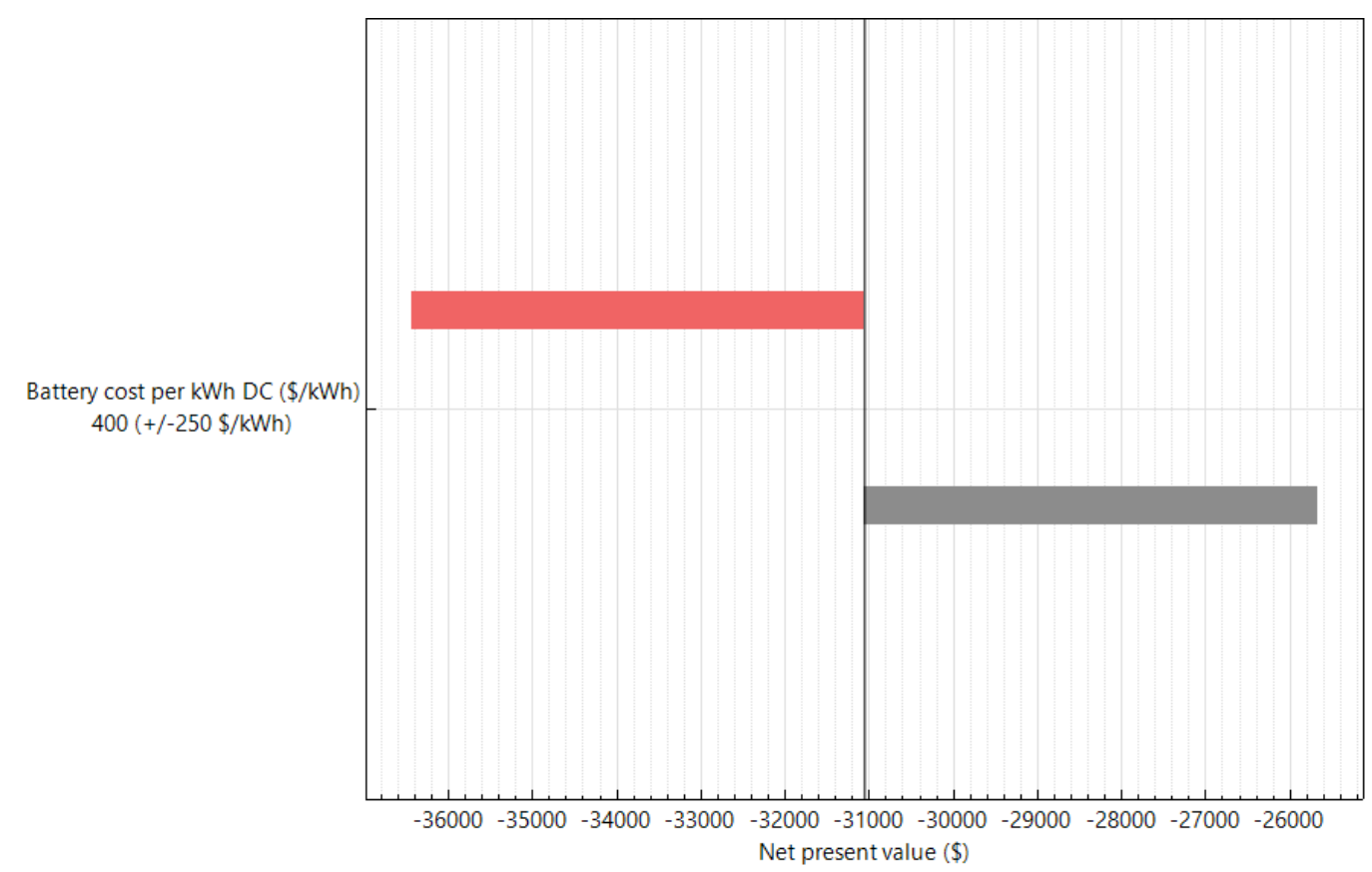

$(--) \square(++)$

Figure 27: variation of NPV with battery cost for the optimal case

Decreasing the battery costs from $400 \$ / \mathrm{kWh}$ to $150 \$ / \mathrm{kWh}$ increased the net present value by $17 \%$ however it remains on the negative side.

\subsubsection{Third-party ownership}

In the third-party ownership scenario, the energy is bought at a fixed rate which is the power PPA rate. The price of energy was set to 10 cents/kWh with an annual escalation rate of $1 \%$. Figure 28 highlights the variation of the net present value for a battery capacity range of 0 
to $150 \mathrm{kWh}$. A positive NPV can be obtained for specific combinations of PV and battery system size. It can be seen that there is an optimal battery size above which the NPV starts to decrease. This is due to the fact that the monthly energy and demand cost reductions become lower than the monthly PPA payments. Compared to the direct ownership model, all combinations resulted in a negative NPV which highlights the advantage of using a PPA to finance the project.

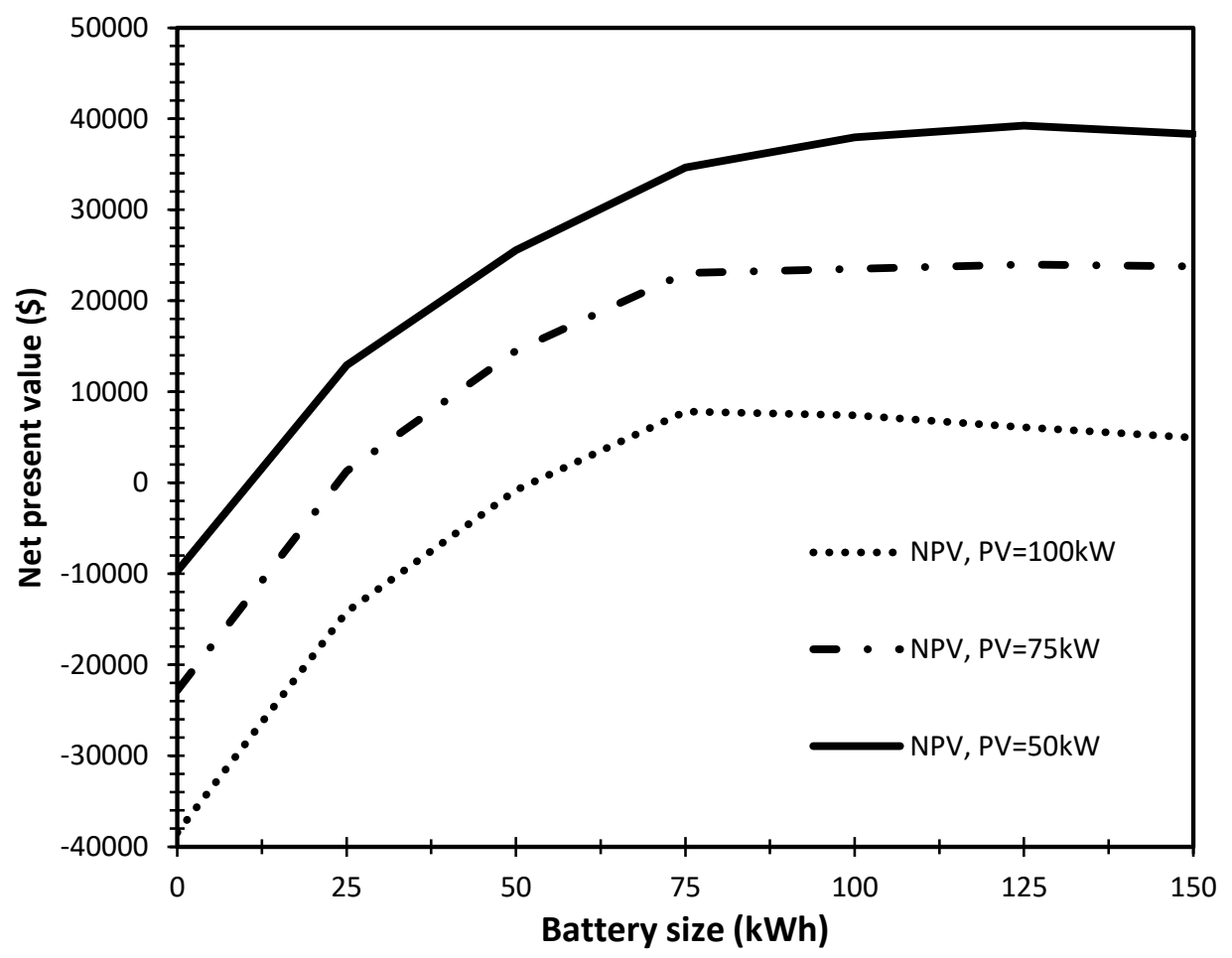

Figure 28: Variation of the net present value with PV system and battery size for a PPA price of 10 cents/kWh

Table 13: Optimal cases for the PPA scenario

\begin{tabular}{|c|c|c|c|c|}
\hline System & Battery (kWh) & SCR (\%) & SSR (\%) & NPV (\$) \\
\hline PV=50kW & 125 & 93.4 & 61.2 & 39254.9 \\
\hline PV=75kW & 125 & 79.3 & 74.3 & 23993.77 \\
\hline $\mathrm{PV}=100 \mathrm{~kW}$ & 75 & 61.4 & 77.7 & 7837.9 \\
\hline
\end{tabular}




\section{CONCLUSIONS}

This project studied the techno-economic feasibility of deploying a PV system for an EV charging station in West Virginia. Using a parametric simulation approach, different combinations of PV and battery system sizes were evaluated to determine their impacts on the system profitability in comparison with grid charging. Two financial models were investigated: direct ownership and third-party ownership of the system. Furthermore, net-metering and the trading of solar renewable energy credits were considered. Based on the data derived in this research, the following conclusions can be derived:

- In terms of $\mathrm{CO}_{2}$ emissions, charging EVs using the grid in West Virginia is comparable to fueling gasoline cars in order to obtain the same mileage.

- Compared to gasoline fueling, when a price of $\$ 2.35 /$ gallon is considered and without accounting for differences in vehicle costs, the PV-EV scenario is found to be economically feasible on the cost of fuel basis only.

- Under the current policies and a SREC price of $\$ 8.5 / \mathrm{MWh}$, charging EVs with PV in WV is not economically feasible compared to grid-EV.

- The PV-EV scenario becomes feasible if SRECs are traded for at least $\$ 100 / \mathrm{MWh}$, which is possible based on the observation of SRECs in Ohio.

- The PV-EV scenario becomes feasible if the commercial system owner chooses to enter a PPA with a maximum price of 7 cents/kWh.

- Optimal sizing of the PV system and the addition of battery storage to the PV-EV station can increase the financial performance of the system without significant reduction in the environmental benefits. 


\section{FUTURE WORK}

A number of limitations which have not been discussed in this study should be addressed in future research. The first limitation consists in not considering the differences in vehicle costs, operation and maintenance expenditures when comparing the PV-EV option to gasoline vehicles. A second limitation is that the results are limited by the range of input parameters and assumptions chosen for this study. For example, the impact of different EV load profiles may yield different results in terms of system sizing and financial performance. Furthermore, the effect of weather on the heating and cooling energy loads may be accounted for when calculating the EV load profile. Moreover, the variation in EV charging patterns was left out of this study due to the uncertainty and difficulty in evaluating these factors. In addition, a larger range of PV and battery system sizes could be considered which will lead to more accurate results. For example, optimal financial and environmental results may be determined by an optimization algorithm instead of parametric simulations. Another limitation can be discussed when considering the PPA financing option. In this study, the economic benefit is assessed from the perspective of the system owner, however the financial analysis should be assessed from the perspective of the system developer as well. 


\section{REFERENCES}

[1] G. J. Thompson, D. K. Carder, M. C. Besch, A. Thiruvengadam, and H. K. Kappanna, "In-use emissions testing of light-duty diesel vehicles in the United States," 2014. [Online]. Available: https://theicct.org/sites/default/files/publications/WVU_LDDV_inuse_ICCT_Report_Final_may2014.pdf.

[2] West Virginia Department of Transportation, "Beneficiary Mitigation Plan, Volkswagen Environmental Mitigation Settlement," 2019. [Online]. Available: https://transportation.wv.gov/highways/programplanning/comment/VW-SettlementMitigation-Plan/Documents/FINAL_VWmitigationPlan_WV.pdf.

[3] J. Mclaren, J. Miller, E. O 'shaughnessy, E. Wood, and E. Shapiro, “CO2 emissions associated with electric vehicle charging: The impact of electricity generation mix, charging infrastructure availability and vehicle type Keywords: CO 2 emissions Carbondioxide Electric vehicles Plug-in electric vehicles PEV Plug-in hybri," Electr. J., no. April, 2016, doi: 10.1016/j.tej.2016.06.005.

[4] U.S Energy Information Administration, "West Virginia State Profile and Energy Estimates," 2018. https://www.eia.gov/state/?sid=WV.

[5] A. R. Bhatti, Z. Salam, M. J. B. A. Aziz, K. P. Yee, and R. H. Ashique, "Electric vehicles charging using photovoltaic: Status and technological review,” Renew. Sustain. Energy Rev., vol. 54, pp. 34-47, 2016, doi: 10.1016/j.rser.2015.09.091.

[6] G. R. Chandra Mouli, P. Bauer, and M. Zeman, "System design for a solar powered electric vehicle charging station for workplaces," Appl. Energy, vol. 168, no. 2016, pp. 434-443, 2016, doi: 10.1016/j.apenergy.2016.01.110. 
[7] S. Mesentean, W. Feucht, H. G. Kula, and H. Frank, "Smart charging of electric scooters for home to work and home to education transports from grid connected photovoltaicsystems," 2010 IEEE Int. Energy Conf. Exhib. EnergyCon 2010, pp. 73-78, 2010, doi: 10.1109/ENERGYCON.2010.5771778.

[8] M. Tesfaye and C. C. Castello, "Minimization of impact from electric vehicle supply equipment to the electric grid using a dynamically controlled battery bank for peak load shaving," 2013 IEEE PES Innov. Smart Grid Technol. Conf. ISGT 2013, pp. 1-6, 2013, doi: 10.1109/ISGT.2013.6497815.

[9] Q. Dai, J. Liu, and Q. Wei, “Optimal photovoltaic/battery energy storage/electric vehicle charging station design based onmulti-agent particle swarm optimization algorithm," Sustain., vol. 11, no. 7, 2019, doi: 10.3390/su11071973.

[10] D. Gudmunds, E. Nyholm, M. Taljegard, and M. Odenberger, "Self-consumption and selfsufficiency for household solar producers when introducing an electric vehicle," Renew. Energy, vol. 148, pp. 1200-1215, 2020, doi: 10.1016/j.renene.2019.10.030.

[11] Sierra Club, D. Chiotos, and D. Kuhnline, "Clean Energy Works in West Virginia,” 2018.

[12] National Renewable Energy Laboratory (NREL), "Using Power Purchase Agreements for Solar Deployment at Universities,” 2016. https://www.nrel.gov/docs/gen/fy16/65567.pdf.

[13] SRECtrade, "Solar Renewable Energy Certificates Markets." https://www.srectrade.com/markets/rps/srec/.

[14] National Renewable Energy Laboratory (NREL), "System Advisor Model (SAM)." https://sam.nrel.gov. 
[15] B. Zhang, Y. Sun, B. Li, and J. Li, "A modeling method for the power demand of electric vehicles based on Monte Carlo simulation," Asia-Pacific Power Energy Eng. Conf. APPEEC, pp. 0-4, 2012, doi: 10.1109/APPEEC.2012.6307215.

[16] M. S. Islam and N. Mithulananthan, "Daily EV load profile of an EV charging station at business premises,” IEEE PES Innov. Smart Grid Technol. Conf. Eur., pp. 787-792, 2016, doi: 10.1109/ISGT-Asia.2016.7796485.

[17] M. M. Elsayed, “Optimum orientation of absorber plates," Sol. Energy, vol. 42, no. 2, pp. 89-102, 1989, doi: 10.1016/0038-092X(89)90136-9.

[18] J. A. Duffie and W. A. Beckman, Solar Engineering of Thermal Processes. New York: John Wiley \& Sons, 1980.

[19] P. . Lunde, Solar Thermal Engineering. New York, 1980.

[20] N. Diorio et al., "Technoeconomic Modeling of Battery Energy Storage in SAM (http://www.nrel.gov/docs/fy15osti/64641.pdf)," 2015. [Online]. Available: http://www.nrel.gov/docs/fy15osti/64641.pdf.

[21] S. Quoilin, K. Kavvadias, A. Mercier, I. Pappone, and A. Zucker, "Quantifying selfconsumption linked to solar home battery systems: Statistical analysis and economic assessment," Appl. Energy, vol. 182, pp. 58-67, 2016, doi:

10.1016/j.apenergy.2016.08.077.

[22] United States Environmental Protection Agency, "Highlights of the Automotive Trends Report.” https://www.epa.gov/automotive-trends/highlights-automotive-trends-report.

[23] U.S Energy Information Administration, "Carbon Dioxide Emissions Coefficients,” 2016. 
https://www.eia.gov/environment/emissions/co2_vol_mass.php.

[24] U.S Energy Information Administration, "How much carbon dioxide is produced per kilowatthour of U.S. electricity generation?,” 2018. https://www.eia.gov/tools/faqs/faq.php?id=74\&t=11.

[25] V. Z. Gjorgievski, N. G. Chatzigeorgiou, V. Venizelou, G. C. Christoforidis, G. E. Georghiou, and G. K. Papagiannis, "Evaluation of load matching indicators in residential PV systems-the case of Cyprus," Energies, vol. 13, no. 8, pp. 1-18, 2020, doi: 10.3390/en13081934.

[26] Monongahela Power Company, "Rules \& Regulations For Electric Service," 2015. [Online]. Available: https://www.firstenergycorp.com/content/dam/customer/Customer Choice/Files/west-virginia/tariffs/WVMPRetailTariff.pdf.

[27] U.S. Department of Energy, "Gas Prices for Cities in West Virginia," 2020. https://www.fueleconomy.gov/feg/gasprices/states/WV.shtml.

[28] R. Fu, D. Feldman, and R. Margolis, "U.S. Solar Photovoltaic System Cost Benchmark: Q1 2018, NREL/TP-6A20-72399.,”2018. [Online]. Available: https://www.nrel.gov/docs/fy19osti/72399.pdf. 


\section{APPENDICES}

Data used for the simulations:

1- Location and Weather file:

Table 14: Location and weather data

\begin{tabular}{|c|c|}
\hline Location & Morgantown, WV \\
\hline Latitude & 39.61 \\
\hline Longitude & -79.94 \\
\hline Time zone & GMT-5 \\
\hline Elevation & $306 \mathrm{~m}$ \\
\hline Average global horizontal irradiance $\left(\mathrm{kWh} / \mathrm{m}^{2} /\right.$ day $)$ & 4 \\
\hline Average temperature $\left({ }^{\circ} \mathrm{C}\right)$ & 11 \\
\hline
\end{tabular}

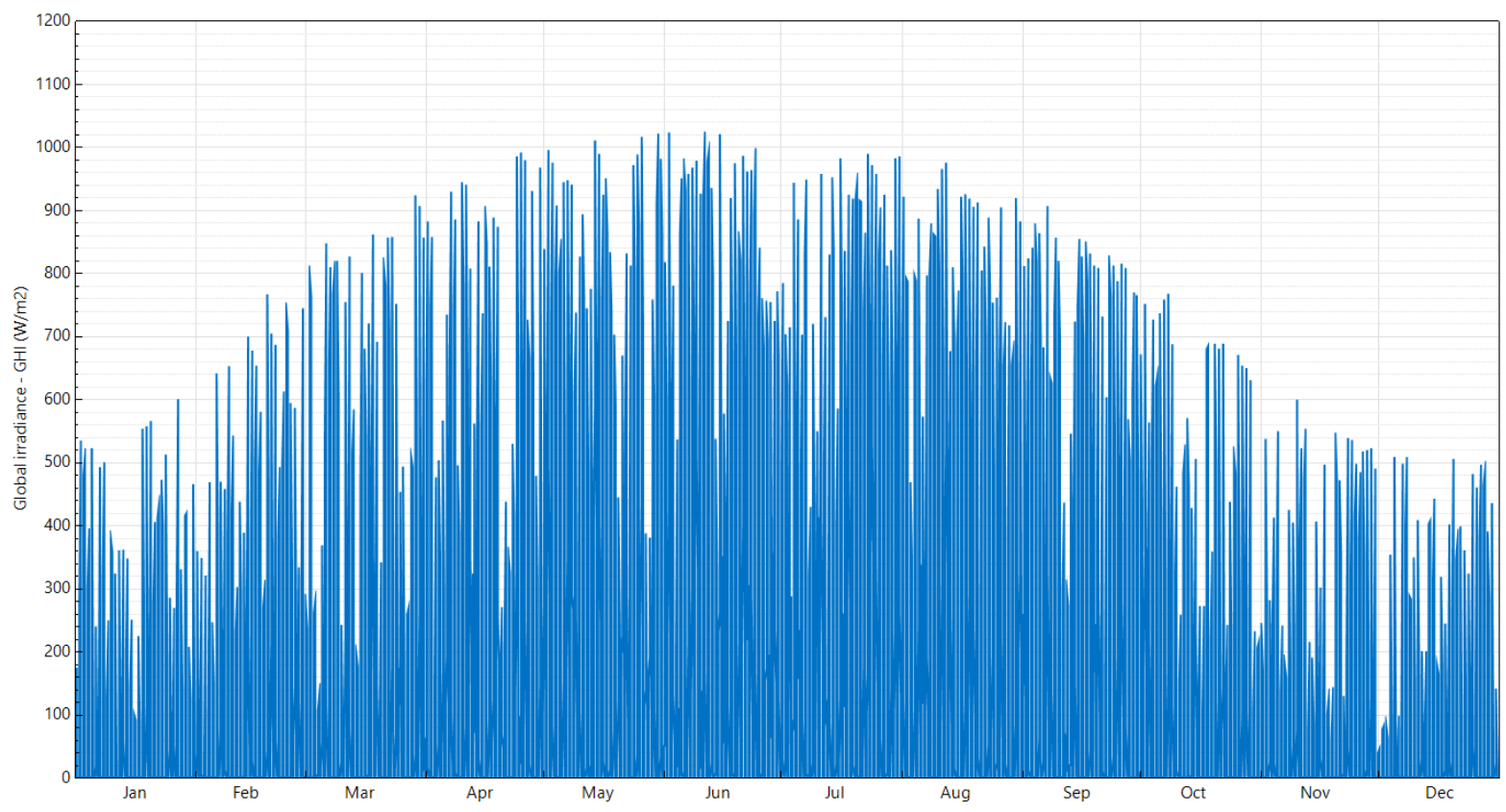

Figure 29: Hourly solar global horizontal irradiance $\left(\mathrm{W} / \mathrm{m}^{2}\right)$ 


\section{2- PV module selection:}

Table 15: PV panel specifications

\begin{tabular}{|c|c|c|}
\hline Property & Unit & Value \\
\hline Solar panel model & - & SunPower SPR-X21-335-BLK \\
\hline Manufacturer & - & MonPower \\
\hline Technology & - & 335 \\
\hline Module power at STC & W & 5.85 \\
\hline Current at Maximum Power Point (Imp) & A & 57.3 \\
\hline Voltage at Maximum Power Point (Vmp) & V & 20.5647 \\
\hline Nominal Efficiency & $\%$ & 6.2 \\
\hline Short Circuit Current (Isc) & A & 67.9 \\
\hline Open Circuit Voltage (Voc) & V & 0.5 \\
\hline Module Performance Degradation Rate & $\% / y e a r$ & \\
\hline
\end{tabular}

SunPower SPR-X21-335

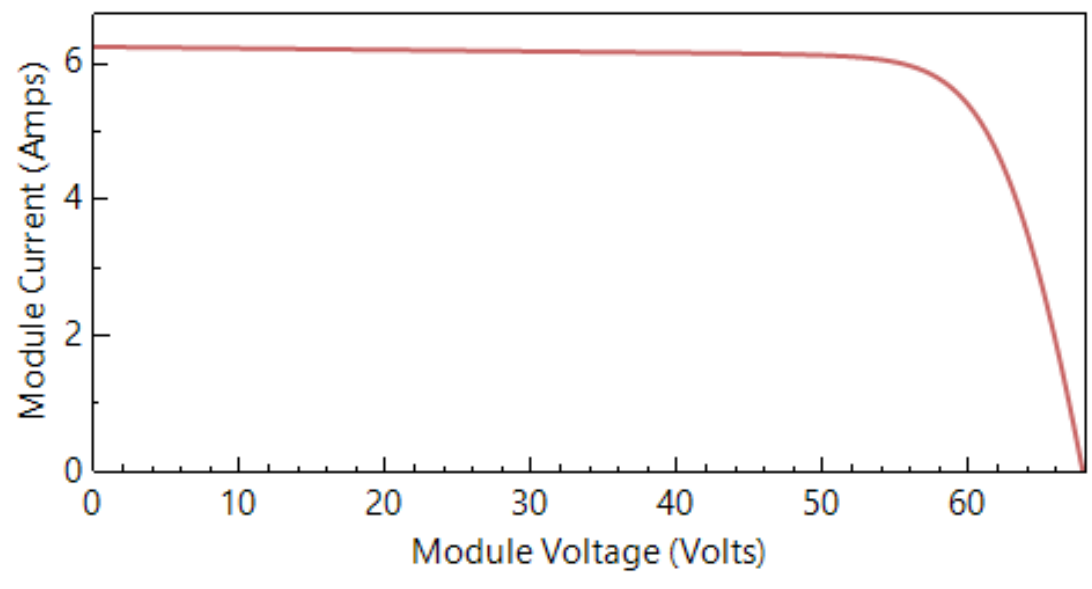

Figure 30: I-V curve of the solar panel 


\section{3- Inverter selection:}

Table 16: Inverter specifications

\begin{tabular}{|c|c|c|}
\hline Property & Unit & Value \\
\hline Inverter model & - & Fronius USA Symo 20.0-3 480V \\
\hline Manufacturer & - & Fronius USA \\
\hline Technology & - & 20000 \\
\hline Maximum AC power & W & 20469.3 \\
\hline Maximum DC power & W & 480 \\
\hline Nominal AC Voltage & V & 800 \\
\hline Maximum DC Voltage & V & 28.749 \\
\hline Maximum DC Current & A & 450 \\
\hline Minimum MPPT DC Voltage & V & 712 \\
\hline Nominal DC Voltage & V & 800 \\
\hline Maximum MPPT DC Voltage & V & \\
\hline
\end{tabular}

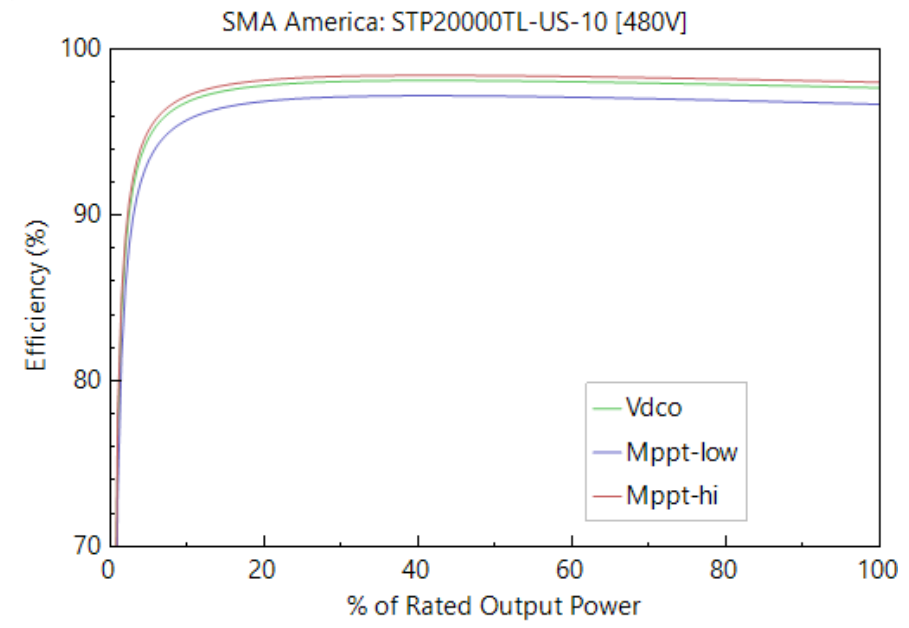

Figure 31: Inverter efficiency at different power output levels 


\section{4- Battery selection:}

Table 17: Battery specifications

\begin{tabular}{|c|c|}
\hline Battery type & Lithium ion \\
\hline Battery Size (kWh) & 100 \\
\hline Battery Power (kW) & 25 \\
\hline Single Cell Capacity (Ah) & 500.4 \\
\hline Battery Voltage (V) & 15985 \\
\hline Total Number of Cells & 139 \\
\hline Cells in Series & 115 \\
\hline Strings in Parallel & 24.937 \\
\hline Maximum Charge/Discharge power (kW) & 6 \\
\hline Discharge Time (hours) & 50 \\
\hline Maximum Charge/Discharge current (A) & 96 \\
\hline Conversion Efficiency (\%) & 80 \\
\hline Depth of Discharge (\%) & 50 \\
\hline Initial State of Charge (\%) & \\
\hline
\end{tabular}




\section{5- Electric vehicle load:}

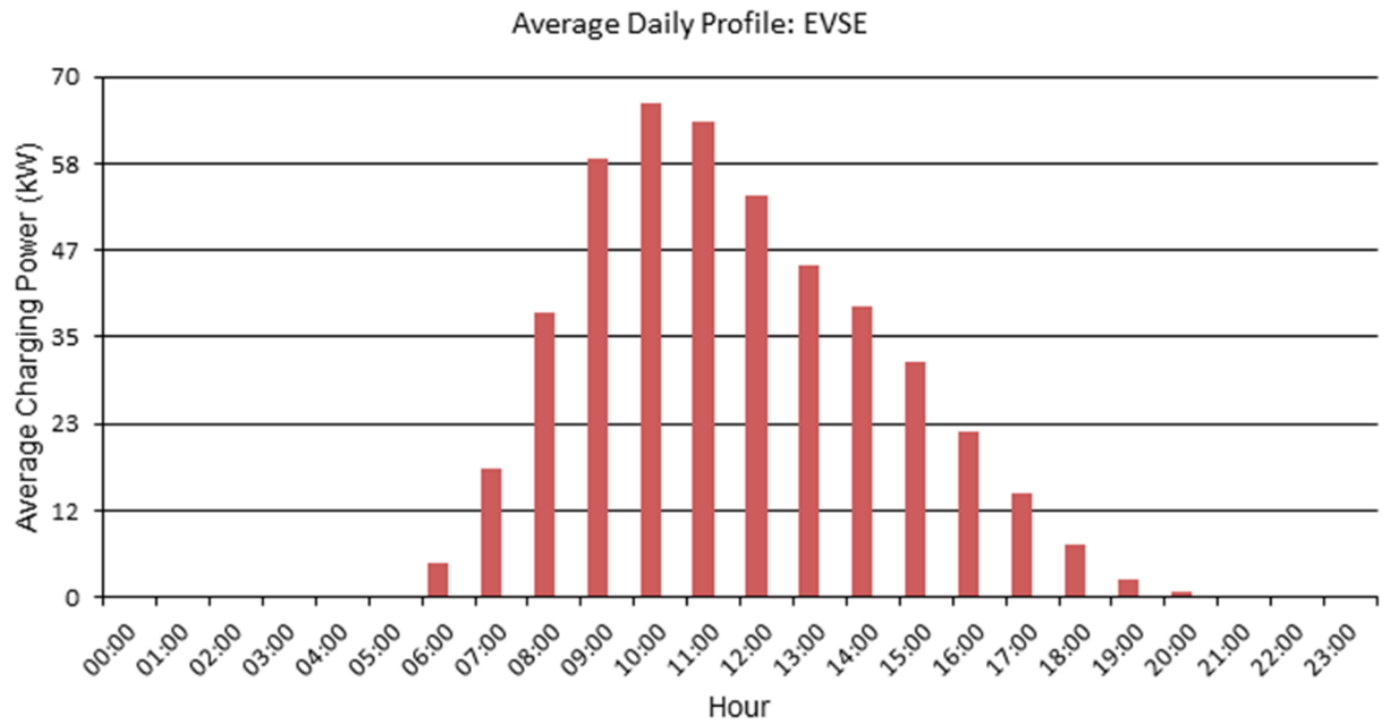

Figure 32: Average daily profile for the electric vehicle charging station 


\section{VITA}

Houssem Eddine Younes was born and raised in Tunis, Tunisia. From 2013 to 2015, Houssem completed the Pre-Engineering Program in Mathematics, Physics and Industrial Sciences at the

Private University of Tunis. After succeeding in the National Examination for Entry to Engineering Schools in 2015, he attended the Energy Engineering Program at the National Engineering School of Monastir and graduated top five of his class in December 2018. Upon his graduation, he worked as a Solar Energy Engineer in Tunisia and in May 2019, he was awarded a Fulbright Scholarship from the U.S Department of State in order to pursue a Master's degree in the United States. In August 2019, he joined West Virginia University to earn a Master of Science in Energy Systems Engineering and completed his degree requirements in July 2020.

\section{Contact information :}

Email : $\underline{\text { houssemeddineyounes@gmail.com }}$

Cell : +216 95616784 